\title{
Can Peers Improve Agricultural Productivity?
}

\author{
Tisorn Songsermsawas \\ Kathy Baylis \\ Ashwini Chhatre \\ Hope Michelson
}

\section{CESIFO WORKING PAPER NO. 4958 \\ CATEGORY 4: LABOUR MARKETS \\ SEPTEMBER 2014}

\footnotetext{
An electronic version of the paper may be downloaded

- from the SSRN website:

- from the RePEc website:

- from the CESifo website:

www.SSRN.com

www.RePEc.org

www.CESifo-group.org/wp
}

\section{CESifo}




\title{
Can Peers Improve Agricultural Productivity?
}

\begin{abstract}
Productivity varies greatly among farmers and the source of that variation is not fully understood. Using a unique Indian household survey, we estimate peer effects on agricultural revenue. Results show that $60 \%$ of farmers' revenue is explained by peers. Input expenditures and land allocation to cash crops do not fully explain the variation in revenue, implying peers may also affect management, negotiation and marketing strategies. We verify that endogenous network formation, geography, off-farm opportunities and agricultural extension do not drive our results. Peer effects are strongest for agricultural peers and in the cultivation of a new crop.
\end{abstract}

JEL-Code: C210, D850, Q120.

Keywords: peer effects, agricultural productivity, India, crop revenue.

Tisorn Songsermsawas

University of Illinois / USA

songser2@illinois.edu

Ashwini Chhatre

Indian School of Business / India ashwini_chhatre@isb.edu
Kathy Baylis

University of Illinois at Urbana-Champaign

USA - 61801 Urbana IL baylis@illinois.edu

Hope Michelson

University of Illinois / USA

hopecm@illinois.edu 


\title{
Can peers improve agricultural productivity?
}

\author{
Tisorn Songsermsawas, Kathy Baylis†, Ashwini Chhatre ${ }^{\ddagger}$ and Hope Michelson ${ }^{\S}$ \\ University of Illinois at Urbana-Champaign
}

\section{Introduction and Motivation}

Why are some farmers more productive than others? In developing countries where markets are frequently incomplete, variation in productivity outcomes can be substantial (Bloom et al., 2013). ${ }^{1}$ This is especially in true agriculture even after accounting for inputs, technology use and agro-climatic factors (Fan et al., 2000; Murgai et al., 2001). One possible explanation for the large variation in productivity is differential access to information. Improvements in access to information about production practices and marketing strategies can improve welfare outcomes (Munshi, 2004; Jensen, 2007; Aker, 2010; Conley and Udry, 2010). Given the limited availability of formal information mechanisms in developing countries, peers may be effective channels for information among farmers. In this paper we ask how learning among peers might help farmers earn higher revenue from selling cash crops. We specifically ask whether cash crop revenue is driven by peer effects and explore whether the effects are driven by input use as in Conley and Udry (2010), by land allocation to a new

${ }^{*}$ Ph.D. Candidate (corresponding author), Agricultural and Consumer Economics, University of Illinois, 1301 W. Gregory Drive, Mumford Hall MC-710, Urbana, IL 61801, USA. Email: songser2@illinois.edu, Tel. +1-217-333-1830, Fax. +1-217-333-1810

${ }^{\dagger}$ Associate Professor, Agricultural and Consumer of Economics, University of Illinois, 1301 W. Gregory Drive, Mumford Hall MC-710, Urbana, IL 61801, USA. Email: baylis@illinois.edu

${ }_{\ddagger}^{\ddagger}$ Associate Professor, Geography, University of Illinois, 605 E. Springfield Avenue, Computer Applications Building MC-150, Champaign, IL 61820, USA. Email: achhatre@illinois.edu

${ }^{\S}$ Assistant Professor, Agricultural and Consumer of Economics, University of Illinois, $1301 \mathrm{~W}$. Gregory Drive, Mumford Hall MC-710, Urbana, IL 61801, USA. Email: hopecm@illinois.edu

${ }^{1}$ There is a growing number of studies in this literature largely in manufacturing and other industrial sectors in developed countries including Ichinowski et al. (1997), Black and Lynch (2001), Bertrand and Schoar (2003), Bartel et al. (2007) and Bloom et al. (2010). 
crop as in Foster and Rosenzweig (1995) and Munshi (2004) or by other factors affecting productivity. $^{2}$

Conley and Udry (2010) document positive peer effects on fertilizer use among pineapple farmers in Southern Ghana while Foster and Rosenzweig (1995) and Munshi (2004) observe peer effects in land allocation among HYV cotton farmers in India. In this paper, we account for both input factors and extend the analysis to peer effects on cash crop revenue, which has a direct implication for household income. Our results provide evidence that these two mechanisms cannot fully explain the peer effects found in cash crop revenue among farmers in our study. This result leads us to hypothesize that there could still be other mechanisms through which peers may affect agricultural productivity such as learning about marketing strategies, negotiation skills and farm practices.

Oster and Thornton (2012) describe three possible mechanisms of information transmission through peers. First, one might simply choose to behave like one's peers. For example, farmers may adopt a new seed simply because their peers use the new seed. Second, one could learn about the benefits of an activity or technology from peers who have experienced positive results. Farmers may adopt a new seed because their peers experienced increased yields after adopting the new variety. Finally, farmers could learn how to use a technology from their peers. Farmers may learn how to cultivate the new seed variety from their peers' prior experience. While we cannot explicitly separate these mechanisms, we explore whether peers' outcomes or peer attributes shape farmers' outcomes.

A critical empirical issue in the peer effects literature is the reflection problem (Manski, 1993), which is the problem of determining whether one's outcome is affected by the outcomes of others in one's group or whether one's outcome affects one's peers. ${ }^{3}$ Three hypotheses

\footnotetext{
${ }^{2}$ In the context of this study, peers or friends could also be members of extended families, relatives and in-laws. We define individuals with whom a farmer reports close relationships to be part of that farmer's peer group. A farmer's social network consists of all the farmers within a village that are linked to your peer group. This is because we only restrict a social network to exist exclusively within a village.

${ }^{3}$ To quote Manski (1993), "The term reflection is appropriate because the problem is similar to that of interpreting the almost simultaneous movements of a person and his reflection in a mirror. Does the mirror image cause the person's movements or reflect them?"
} 
could explain why individuals have similar outcomes as their peers. The first hypothesis is an individual's outcome varies depending on behaviors of other individuals in the same peer group. This effect is called the endogenous effect. For example, suppose there are two peer farmers A and B. A and B earn similar cash crop revenue because A and B discuss when to harvest their crops and sell at the same time, resulting in similar prices. Second, an individual's outcome could depend on observed attributes of peers within the same group. This effect is called the exogenous effect. If a farmer in a peer group owns cattle and lends them to peers, since access to drafted cattle and their manure can help farmers raise their productivity, other farmers in the same peer group attain greater productivity due to cattle ownership of one farmer. Finally, individuals could experience similar outcomes as their peers because they are exposed to a similar environment, known as the correlated effect. For example, assume farmers $\mathrm{A}$ and $\mathrm{B}$ live in the same village and travel to the same market to sell their crops. Since crop prices are determined by the market, they are likely to receive similar prices and report similar earnings from their farms. ${ }^{4}$

Using a household survey conducted in Thaltukhod Valley, Himachal Pradesh, India, we test whether a household's farm revenue is dependent on the outcome of their peers. Households were asked to list up to five closest peers within the same village from whom they seek advice most frequently in general, and specifically for agricultural matters. ${ }^{5}$ Taking advantage of these rich social network data, we follow the framework developed by Manski (1993), Brock and Durlauf (2001) and Moffitt (2001), and adopted by Bramoullé et al. (2009) to identify both endogenous peer effects and peer effects from peers' characteristics on cash crop revenue.

We find substantial positive peer effects on cash crop revenue among farmers. Almost

\footnotetext{
${ }^{4}$ In this paper, we cannot explicitly control for the correlated effect. However, if the correlated effect has a similar impact of all individuals within a network, we account for that by including network fixed effects. But if the correlated effect has differential impact on different individuals within a network, and that impact also varies according to the network structure and leads to individuals having differential outcomes, we cannot account for such correlated effect in our study.

${ }^{5}$ A similar survey question is used in Bramoullé et al. (2009) who use information about peer relationships (up to five male and five female friends) to derive the demand for consumption of recreational activities among U.S. high school students.
} 
$60 \%$ of a farmer's cash crop revenue is explained by the revenue of her peers. By testing for learning mechanisms, we find that social learning takes place through pesticide use and allocation of land for growing peas, a new cash crop in the area. Notably, pesticide use is not explained by geographic peers, thus we observe more than the outcome of a locationallyspecific pest outbreak. Pest infestations are sporadic and could vary greatly from year to year and thus any individual farmer might not have experience except through their peers' information. Second, peas were recently introduced into the area not long before the survey was conducted. Therefore, optimal pesticide use and pea cultivation might necessitate information from peers. We also find that peer effects are stronger for agricultural peers than general peers. These results are evidence of social learning among peer farmers.

One might be worried that there could be a number of unobservable factors driving our results. Therefore, we control for factors including households' observed attributes, location, off-farm income opportunities and frequency of contacts with local agricultural extension. Although we cannot account for correlated effects that could vary across networks, we control for factors specific to each network including distance to market using network fixed effects. Further, to address concerns that peer effects are driven largely by geography and unobserved land characteristics affecting production potential, we conduct a number of robustness checks and find that these factors do not significantly affect cash crop revenue among peers. Finally, one might worry that the potential endogeneity arising from peers' self-selecting to become friends. We test for this concern and find that exogenous characteristics such as caste and geographic proximity (neighborhood) are good predictors of peer networks, implying that our observed networks are largely exogenous.

This study makes two primary contributions to the literature on agricultural productivity and peer effects. First, to the best of our knowledge, ours is among the first studies to estimate peer effects on cash crop revenue. While the existing literature on peer effects in agriculture generally focuses on technology adoption (Bandiera and Rasul, 2006; Duflo et al., 2008), specifically input use (Conley and Udry, 2010) and land allocation (Munshi, 2004), 
our study focuses on revenue, which is arguably more closely related to household income and therefore welfare. Further, our study extends the analysis to investigate the channels through which social learning takes place and find that input use and land allocation cannot fully explain peer effects on cash crop revenue among Thaltukhod farmers. Second, our research is one of the first studies on peer effects in agriculture based on social network data for the entire village. The survey contains social network information from all households in 17 villages in the Thaltukhod Valley in Himachal Pradesh, India, similar to the data used in van den Broeck and Dercon (2011). Previous studies either lack individual-level network data or use sampled network data, which could lead to biased estimates (Foster and Rosenzweig, 1995; Kremer and Miguel, 2007).

Our results have two important policy implications. First, as has been argued elsewhere (Foster and Rosenzweig, 1995; Conley and Udry, 2010), the introduction of a new technology or information could greatly benefit from peer effects. Under limited resources, agricultural extension or the new implementing institution might train a small number of farmers and then let these farmers teach their peers about a new technology onwards. However, such information transmission of a new technology might not take place as effectively if peer groups are segregated because the information might not be able to reach certain farmers who are not part of the targeted groups. Therefore, extensive coverage and appropriate targeting are important in technology adoption. Second, our results also provide evidence that peer effects could explain differential productivity outcomes beyond technology adoption and input use. To further improve farm productivity, policy makers might consider finding ways to help small-scale farmers improve their marketing strategies, negotiation skills and farm practices, and harnessing peer networks to do so. 


\section{Literature Review}

\subsection{How can peer networks improve economic outcomes?}

Several studies have investigated the role of social interaction on various economic outcomes including technology adoption (Besley and Case, 1994; Foster and Rosenzweig, 1995; Conley and Udry, 2010), diffusion of information (van den Broeck and Dercon, 2011; Banerjee et al., 2013) and risk sharing (de Weerdt and Dercon, 2006; Fafchamps and Gubert, 2007; de Weerdt and Fafchamps, 2011). Our study poses a similar question: What is the correlation between peer effects and economic outcomes? In particular, we investigate how peer effects though social networks associate with cash crop revenue of small-scale households in rural India.

Previous research on agricultural production has found mixed results on the relationship between social interactions and economic outcomes. While many studies find evidence of positive peer effects (Foster and Rosenzweig, 1995; Munshi, 2003, 2004; Bandiera and Rasul, 2006; Conley and Udry, 2010; Duflo et al., 2011), recent randomized controlled trials investigating the effect of peers' experience on agricultural production find either no significant effect (Duflo et al., 2008) or negative effect (Kremer and Miguel, 2007).

A study by Conley and Udry (2010) is one of the first to use explicit information about personal relationships to study the effects of social learning on input use among pineapple farmers in Southern Ghana. Conley and Udry (2010) find evidence that farmers adjust the amount of fertilizer applied onto their pineapple plots based on positive productivity outcomes or "good news" of their peers. Although the authors did not explicitly control for the reflection problem, they argue that in their setting, it is implausible for farmers to decide their fertilizer use up to two years in advance before deciding who to go ask for advice.

Bramoullé et al. (2009) account for the reflection problem by adopting the approach in Lee (2007) to disentangle peer effects in a social network framework. They use Monte Carlo simulations to demonstrate the procedure to estimate peer effects on the use of recreational 
services among secondary school students. They find that exogenous and endogenous effects can be separated using explicit information about social relationships, and their results correspond to those of other studies using social networks to estimate peer effects (Giorgi et al., 2010; Lin, 2010).

Another challenge in the estimation of peer effects is the presence of correlated effects. Individuals could have similar outcomes simply because they are exposed to similar contextual settings (Manski, 1993). To address this challenge, a few studies randomly assign individuals to form peer groups and observe their outcomes. Sacerdote (2001) finds significant peer effects on academic performance and participation in social groups among Dartmouth students assigned to live in the same rooms and dorms. Significant peer effects are also observed in other similar studies including among first-year roommates at Williams College (Zimmerman, 2003), students at the U.S. Air Force Academy (Carrell et al., 2009) and MBA

roommates in India (Jain and Kapoor, 2014). On the other hand, Foster (2006) and Lyle (2007) do not find significant effects of peers among randomly assigned college roommates at the University of Maryland and among cadets in social groups at West Point.

\subsection{How can peer networks improve agricultural productivity?}

Peers may be particularly important for improving agricultural productivity in developing countries. A number of production constraints pose challenges on farm productivity, which can include environmental and resource constraints (Ruttan, 2002), liquidity constraints (Barrett et al., 2005), knowledge and technological constraints (Feder et al., 1985) and information constraints (Goyal, 2010). As the transaction costs to overcome these constraints may be substantial for small-scale farmers in developing countries, peers are attractive channels to which they could turn to for help (Durlauf and Fafchamps, 2005).

Small-scale farmers could greatly benefit from improved information (Jensen, 2007; Aker, 2010) and social learning (Conley and Udry, 2010; van Rijn et al., 2012). However, farmers do not always have equal access to market information. One possible option to help farmers 
overcome the information barrier is through communication with their peers. Also, the interaction between peers could foster other factors beneficial to agricultural productivity including labor exchange, gift reciprocity and social learning.

\subsection{How can spatial dependence explain agricultural productiv- ity?}

Spatial dependence is an underlying factor in determining agricultural productivity. Spatial dependence may capture agro-climatic attributes including soil quality and amount of rainfall (Holloway et al., 2002). Economic studies of agricultural production have benefited from the growing number of spatially explicit data available to account for spatial dependence. These data allow economists to apply spatial econometric models to tackle problems in applied economics related to the environment, resources and agriculture at multiple scales including plot, household, village and regional levels. ${ }^{6}$

With regards to agricultural production, one of the first studies to use spatial econometric models to study agricultural production was Holloway et al. (2002). The authors investigate the diffusion of high-yielding variety (HYV) rice among farmers in Bangladesh. They find significant and positive neighborhood effects of adoption. ${ }^{7}$ Similarly, Langyintuo and Mekuria (2008) find strong neighborhood effects on land allocation decisions of maize farmers in Mozambique. More recent applications of spatial dependence among peers in technological adoption in an agricultural setting include Liverpool-Tasie and Winter-Nelson (2012), Maertens and Barrett (2013) and Genius et al. (2014).

Subsequent studies which use spatial econometric models to study agricultural production also take advantage of the increasingly available GIS generated variables to account for the effects of geographical distance. Other studies on agricultural production also highlight the

\footnotetext{
${ }^{6} \mathrm{~A}$ detailed review of economic studies with spatially explicit data can be found in Bell and Dalton (2007).

${ }^{7}$ Neighborhood effects capture whether rice farmers in the same area also cultivate HYV rice.
} 
importance of controlling spatially related attributes. ${ }^{8}$ These studies find that taking spatial dependence into account produces very different estimation results compared to estimating the models that cannot control for spatial dependence. In this paper, we apply similar spatial econometric methods to estimate peer effects.

\section{Setting and Data}

\subsection{Setting}

Our data come from a household survey of small-scale farmers in Thaltukhod Valley, Himachal Pradesh, India. Figure 1 presents a map of the study area. The survey gathered information on all 522 households living in 17 villages in the Valley. However, due to missing data, the total number of observations used in this study is 509. Each village is of different sizes (between 11 and 66 households) and is located at different elevations throughout the Valley.

[Figure 1 around here]

Like elsewhere in rural India, the majority of the population in Thaltukhod are smallscale farmers. Main sources of household income include cash crop cultivation, livestock rearing and civil service jobs. Farmers also rely on the forest neighboring each village for fuel wood gathering (both for use and for sale), livestock grazing and collection of fodder, timber and medicinal herbs. Households in each village own between two and seven plots varying in size, elevation, slope and aspect. Some plots are shared among households in the same village. Within each plot, each household owns a specific parcel. These parcels vary in size within and across villages.

In 2008, a comprehensive survey was administered to all households. Households were asked detailed questions about their livelihood activities for the previous five years (2004-

\footnotetext{
${ }^{8}$ See Pattanayak and Butry (2005) and Sarmiento and Wilson (2008), among others.
} 
2008), and ten years ago (1998). The survey also collected detailed social network information for every household. Households were also asked detailed modules about cropping rotation, land allocation decisions and input expenditures, revenue from sales of cash crops and marketing channels.

Households grow three main cash crops: kidney beans, potatoes and green peas and three main food crops: maize, wheat and barley. Kidney beans and potatoes are traditional cash crops in Thaltukhod. However, peas were introduced recently, first appearing five years before the survey was conducted. According to the data from the survey, all households grow at least one of the three cash crops annually. Farmers sell cash crops in a centralized market located down the Valley to agricultural traders. Based on anecdotal evidence, the price of the crops farmers receive depends mostly on the timing of sales and quality.

With regards to social network data, households were asked two questions about their social peers within its own village. ${ }^{9}$ They were asked to name up to three households they seek advice from most frequently for general livelihood matters. Approximately $45 \%$ of the households named only two other households in this category, while the remaining households named three. Households were also asked to list up to two more households they ask for advice specifically about cash crops. We use the combination of these two sets to form the peer group for each household. Thus, households can list up to the maximum of five different households within the same village as peers. Of the two categories, $30 \%$ of the households list five different peers in the two categories and $25 \%$ of the households reported that their closest agricultural peers are also their general peers.

\subsection{Data}

To estimate peer effects on cash crop revenue among rural Indian farmers, we first calculate the total cash crop revenue from all sales (in rupees) in a growing season for each

\footnotetext{
${ }^{9}$ In this study, we assume a closed network at the village level only. Therefore, we assume that crossvillage relationships are not particularly strong. This assumption is supported by anecdotal evidence from the initial field work in the area.
} 
household. ${ }^{10}$ We use this variable as the main dependent variable to test peer effects on cash crop revenue. ${ }^{11}$ We construct a weights matrix based on stated personal relationships among households, which identify the peer groups in a given social network. Then, we incorporate weights matrix of social interaction to the regressions. This approach allows us to separate exogenous and endogenous effects of peers on cash crop revenue of Thaltukhod farmers.

\section{[Table 1 around here]}

The summary statistics of the households in our dataset are shown in Table 1. An average household has 5.71 members, of which 1.76 persons are between the age of $0-14,3.61$ persons are between the ages of 15-60, and 0.35 persons are above 60 years old. $85 \%$ of the households belong to the higher of the two castes represented in the area. In each household, $40 \%$ of all members report at least eight years of education, which is the compulsory education level in India. Each household owns 8.18 bhigas of land and 6.204 of which is allocated to grow cash crops. ${ }^{12}$ The average livestock holding (by headcount) of households is 0.57 units. Households own plots that are situated 2,006 meters above the sea level and have an average of 26.18 degrees of slope. Each household earns on average 3,106 rupees from off-farm activities, 139 rupees from forest resources and 9,392 rupees from all cash crop sales during the past 12 months preceding the survey. ${ }^{13} 98 \%$ of the households reported to have been in contact with the local agricultural extension (from the Indian Ministry of Agriculture) and each household reported talking with the local extension agent about five times in the last 12 months proceeding of survey.

[Figure 2 around here]

\footnotetext{
${ }^{10}$ The total revenue variable is the sum of total sales in rupees of farm households of their kidney beans, potatoes and peas.

${ }^{11}$ The reason we pick this variable as the main dependent variable is because in our dataset, cash crop revenue is reported separately from each type of cash crop sold, other agricultural income, labor income, forest income and other sources of income. The input variables, however, are not broken down by crop.

${ }^{12} 1$ bhiga $=0.2$ acres $=0.0809$ hectares.

${ }^{13} 1$ Indian rupee was approximately $\$ 0.02$ in 2008 (year of survey).
} 
Households exhibit considerable variation in cash crop revenue across households and across villages, ranging from 500 to 95,400 rupees in a growing season. We present the kernel density estimation of total cash crop revenue across all households in Figure 2 and that of cash crop revenue across four randomly selected villages in Figure 3. These two figures help illustrate that there exists considerable heterogeneity in cash crop revenue both within and across villages.

\section{Theoretical Framework}

Suppose each farmer $i$ is a risk-neutral agent who seeks to maximize expected profits. Let $w_{i}$ account for peer effects across farmers. ${ }^{14}$ This correlation among farmers $w_{i}$ can be either exogenous (observed attributes of peers) or endogenous (outcome of peers) effects of peers, which are channels through which peers learn from each other. Let a farmer's cash crop revenue be a function of the following components

$$
R_{i h}=P_{i h} F\left(A_{i h}, K_{i h}, T_{i h}\right)
$$

where $R_{i h}$ is the revenue from total sales of cash crop $h$ grown by farmer $i, P_{i h}$ is the price per unit of crop $h$ farmer $i$ receives from total sale of crop $h, A_{i h}$ is the total factor productivity (TFP) which is the unobserved component of farmer $i$ 's production of crop $h, K_{i h}$ is the aggregate investment used by farmer $i$ for crop $h, T_{i h}$ is the land area farmer $h$ allocates for crop $h$ and $f($.$) represents the production function (technology).$

In this paper, we test three main hypotheses. First, we test whether there is a relationship between farmers' cash crop revenue and their peers' revenue. That is, we test whether the following relationship exists

$$
R_{i h}=f\left(w_{i} r_{i h}\right) .
$$

\footnotetext{
${ }^{14}$ This model specification assumes that this correlation among peers $w_{i}$ is known to the farmers, but not to the researcher.
} 
Further, to explore the possible learning mechanisms, we test whether there exists a relationship between farmers' optimal choices of input expenditures and land allocation to growing cash crops and their peers' choices. Specifically, we test for the two following relationships.

$$
\begin{aligned}
& K_{i h}^{*}=f\left(w_{i} k_{i h}^{*} \mid R_{i h}\right) . \\
& T_{i h}^{*}=f\left(w_{i} t_{i h}^{*} \mid R_{i h}\right) .
\end{aligned}
$$

However, farmers' cash crop revenue could also be explained by peer effects in total factor productivity (TFP), which includes several attributes namely management skills, negotiation ability access to information. Therefore, in this study, we ask whether the following relationship exists.

$$
A_{i h}=f\left(w_{i} a_{i h} \mid R_{i h}\right)
$$

\section{$5 \quad$ Identification Strategy}

\subsection{Identification of Peer Effects}

The empirical model to investigate peer effects and agricultural revenue closely follows the standard linear-in-means model as found in Moffitt (2001). ${ }^{15}$ We adopt the specification in Lee (2007) and Bramoullé et al. (2009) of the linear-in-means model to identify peer effects through social network by using the variation of outcomes within each peer group to identify peer effects on cash crop revenue among Thaltukhod farmers.

Given a population of size $L$, suppose that each household (or farmer) $i,(i=1, \ldots, n)$ belongs to a specific peer group $S_{i}$ of size $n_{i}$ containing peers $j$. Households do not belong

\footnotetext{
${ }^{15}$ In a linear-in-means model, each individual's outcome has a linear relationship with own individual characteristics, the average outcome of peers in a reference group and their individual characteristics, as explained in detail in Lee (2007) and Bramoullé et al. (2009).
} 
to their own peer groups, $i \notin S_{i}$. Let $y_{i}$ be the total cash crop revenue of household $i$. Let $x_{i}$ denote observed individual characteristics of household $i$ and there are $k,(k=1, \ldots, K)$ characteristics. Specifically, the model can be expressed as follows:

$$
y_{i}=\alpha+\beta \frac{\sum_{j \in S_{i}} y_{j}}{n_{i}}+\gamma x_{i}+\delta \frac{\sum_{j \in S_{i}} x_{j}}{n_{i}}+\epsilon_{i}
$$

where the parameters $\beta$ and $\delta$ capture endogenous and exogenous effects.

Similar to the constraint imposed by Bramoullé et al. (2009), we require that $|\beta|<1 .^{16}$ The error term $\epsilon_{i}$ captures each household's unobserved individual characteristics. These unobserved characteristics are assumed to be strictly exogenous, which implies $E\left[\epsilon_{i} \mid x_{i}\right]=$ 0. This specification assumes that i.i.d. samples are drawn from a population of size $L$ with a fixed and known network structure and strict exogeneity (Bramoullé et al., 2009). Alternatively, this structural model can be illustrated in matrix form given below:

$$
\boldsymbol{y}=\boldsymbol{l}^{\prime} \alpha+\boldsymbol{G} \boldsymbol{y}^{\prime} \beta+\boldsymbol{x}^{\prime} \gamma+\boldsymbol{G} \boldsymbol{x}^{\prime} \delta+\boldsymbol{\epsilon}
$$

where $\boldsymbol{y}$ represents an $n \times 1$ vector of outcomes for the entire population, $\boldsymbol{l}$ is an $n \times 1$ vector of ones, $\boldsymbol{x}$ is an $n \times k$ vector of observed individual characteristics, $\boldsymbol{G}$ is a $n \times n$ weights matrix indicating personal relationships between two households where $G_{i j}=\frac{1}{n_{i}}$ if household $i$ is a friend of household $j$ and 0 otherwise. ${ }^{17}$ Therefore, the matrix $\boldsymbol{G}$ represents the peer groups for each household in the data. ${ }^{18}$

All social ties considered are directed but unweighted. ${ }^{19}$ Under this specification, the parameter $\beta$ resembles the spatial auto-regressive coefficient in a typical spatial lag model.

\footnotetext{
${ }^{16}$ This condition restricts that one's own outcome cannot be dominated by the marginal effects of peers.

${ }^{17}$ The row-normalization of the interaction matrix $\boldsymbol{G}$ assumes that peers have similar weights for one's outcome. This can address the potential bias of top-coding.

${ }^{18}$ We row normalize the weights matrix according to the specification in Bramoulle et al. (2009), which imposes an assumption that individuals who list fewer peers will receive higher weights on each peer for their outcome.

${ }^{19}$ Household $i$ is linked to household $j$ with a directed only if household $i$ reported household $j$ as one of their peers, but not vice versa. The link between households $i$ and $j$ is unweighted because it does not take into account the strength of the tie.
} 
Our identification of peer effects through social networks uses the variation in agricultural productivity levels of peers (endogenous effects) and individual characteristics of peers (exogenous effects) to explain a household's productivity.

\subsection{Instrumentation for Endogenous Peers Effects}

The identification strategy adopted from the standard linear-in-means model as proposed by Moffitt (2001) allows us to estimate the exogenous and endogenous effects of peers separately. However, the effect of the average outcome of peers in a peer group is endogenous. The endogeneity problem arises because one's outcome and the average outcome of one's peers can be correlated with common unobserved characteristics. This correlation needs to be corrected for endogeneity (Wooldridge, 2010). Since it is likely that peers who belong to the same peer group will have similar outcomes, the failure to correct for the endogeneity of average outcome of peers will lead to biased estimates of peer effects.

We employ a generalized two-stage least squares (2SLS) method as suggested by Kelejian and Prucha (1998), with modifications by Lee (2007). ${ }^{20}$ This approach uses the average of friends of friends' observed attributes as the instrument set for the average outcome of members of one's peer group (Bramoullé et al., 2009). In other words, $\boldsymbol{G}^{2} \boldsymbol{x}$ is the instrument set for $\boldsymbol{G} \boldsymbol{y}$, which contains the observed attributes of friends of friends. ${ }^{21}$ The validity of this instrument set is discussed extensively in Manski (1993), Moffitt (2001) and Lee (2007). Since the average of individual characteristics of one's friends of friends' are exogenous to one's own outcome and are correlated with the average outcome of one's friends, it satisfies the exclusion restriction to be a valid instrument set for the average outcome of one's friends. ${ }^{22}$ That is, the observed attributes of friends of friends can only affect one's outcome level through the average outcome of friends.

Bramoullé et al. (2009) explain how this set of instruments can identify peer effects

\footnotetext{
${ }^{20}$ Bramoullé et al. (2009) note that since this approach does not assume homoskedasticity, parameters estimates are only consistent, but not asymptotically normal.

${ }^{21}$ This instrument set is also used in the empirical part in Bramoullé et al. (2009).

${ }^{22}$ See Equation (4).
} 
through social networks. First, consider Equation (7), since generally $|\beta|<1$ and the matrix $\boldsymbol{I}-\beta \boldsymbol{G}$ is invertible, the reduced form of Equation (7) can be written as follows:

$$
\boldsymbol{y}=\alpha(\boldsymbol{I}-\beta \boldsymbol{G})^{-1} \boldsymbol{l}+(\boldsymbol{I}-\beta \boldsymbol{G})^{-1}(\gamma \boldsymbol{I}+\delta \boldsymbol{G}) \boldsymbol{x}+(\boldsymbol{I}-\beta \boldsymbol{G})^{-1} \boldsymbol{\epsilon}
$$

As $(\boldsymbol{I}-\beta \boldsymbol{G})^{-1}=\sum_{k=0}^{\infty} \beta^{k} \boldsymbol{G}^{k}$ and there is no household with no peers, we can rewrite Equation (8) as follows:

$$
\boldsymbol{y}=\frac{\alpha}{(1-\beta)} \boldsymbol{l}+\gamma \boldsymbol{x}+(\gamma \beta+\delta) \sum_{k=0}^{\infty} \beta^{k} \boldsymbol{G}^{k+1} \boldsymbol{x}+\sum_{k=0}^{\infty} \beta^{k} \boldsymbol{G}^{k} \boldsymbol{\epsilon}
$$

Thus, we can rewrite Equation (9) in terms of the conditional expectation of the cash crop revenue of peers in one's peer group on $\boldsymbol{x}$ as follows:

$$
E[\boldsymbol{G} \boldsymbol{y} \mid \boldsymbol{x}]=\frac{\alpha}{(1-\beta)} \boldsymbol{l}+\gamma \boldsymbol{G} \boldsymbol{x}+(\gamma \beta+\delta) \sum_{k=0}^{\infty} \beta^{k} \boldsymbol{G}^{k+2} \boldsymbol{x}
$$

From Equation (10), the conditional expectation of the average cash crop revenue of peers in one's peer group on $\boldsymbol{x}$ can be expressed further as:

$$
E[\boldsymbol{G} \boldsymbol{y} \mid \boldsymbol{x}]=\frac{\alpha}{(1-\beta)} \boldsymbol{l}+b_{0} \boldsymbol{x}+b_{1} \boldsymbol{G} \boldsymbol{x}+b_{2} \boldsymbol{G}^{2} \boldsymbol{x}
$$

where $b_{2} \neq 0$ if $\beta \neq 0$ and $\gamma \beta+\delta \neq 0 .{ }^{23}$ Thus, Lee (2007) shows that one can use $\boldsymbol{G}^{2} \boldsymbol{x}$ as a valid instrument set for $\boldsymbol{G} \boldsymbol{y}$. Under this specification, peer effects through social network can be identified. ${ }^{24}$

\footnotetext{
${ }^{23}$ Detailed derivations of Equation (7) can be found in Bramoullé et al. (2009).

${ }^{24}$ Lee (2007) also assumes in this model specification that there is no specific group fixed effects.
} 


\subsection{Challenges to the Identification Strategy}

\subsubsection{Correlated Effects}

One might be concerned that our identification strategy that uses the variation in the outcome of peers within each peer group might contain omitted variable bias from unobserved heterogeneity across different networks. To account for this issue, we add network-level fixed effects into the regression models. The network fixed effects will remove any variation across different network. ${ }^{25}$ The network fixed effects, however, cannot capture any variation within each network.

In the context of this study, the variations within each village could be thought of as a correlated effect as mentioned in Manski (1993). Since we cannot control explicitly for the variation within each network (or village), we have to proceed with the assumption that the correlated effects arising from the variation within different networks (or villages) are negligible. This assumption is a limitation of the identification strategy in this study. However, we have empirical evidence that exogenous characteristics namely caste and proximity are good indicators of peers, which could help reconcile the assumption that social networks are formed exogenously among peers.

\subsubsection{Geography}

Geography is a crucial determinant of agricultural profitability. Location affects both agronomic factors including rainfall, temperature and soil quality, and physical factors such as transportation cost. Farmers growing their cash crops at a higher elevation might receive in very different yields from farmers with plots at a much lower elevation due to differences in temperature and rainfall. In Thaltukhod Valley, elevation is particularly important for farmers who grow peas. Peas grown at higher elevation take longer to mature and farmers who grow at a higher elevation tend to receive lower prices due to harvest timing. Similarly,

\footnotetext{
${ }^{25}$ This is to account for the fact that farmers in certain networks are generally more productive than those others.
} 
farmers who grow cash crops on a plot with a steep slope cannot grow as many units of crops on the same amount of land as farmers who grow their crops on a flatter plot.

To capture the possible effects of geography on cash crop revenue, we include three variables; distance to the main trading location, elevation and slope. Distance to the main trading location stop is measured by the Euclidean distance to the main market in Thaltukhod Valley. Elevation is measured in meters above the average sea level and slope is measured in degrees.

\subsubsection{Off-farm Income Opportunities}

In any growing season, information about price and production uncertainty in the market of cash crops could discourage farmers from investing a significant amount of time, effort and resources into their cash crop production. The incomplete nature of the cash crop market in a rural economy leads to a greater need to search for off-farm income sources for small-farm households. These off-farm income opportunities help farmers stabilize household income. ${ }^{26}$ Since information about off-farm income opportunities may be transmitted through interactions of households in the same peer group, it is important that we control for this factor.

To control for off-farm income opportunities of farmers in the Thaltukhod Valley, we include determinants of the amount of income households could earn off-farm. Specifically, we control for the distance to the nearest bus stop and the interaction term between this distance and the number of family members between 15 and 60 years old. As noted by Bell and Dalton (2007), distance to the closest paved road indicates the access to formal markets, which could determine the degree of market participation (Abdulai and Huffman, 2005) and off-farm labor supply (Fafchamps and Shilpi, 2003). ${ }^{27}$

\footnotetext{
${ }^{26}$ A review article by de Janvry and Sadoulet (2006) provides a detailed explanation of potential off-farm income opportunities due to market imperfections. For more formal and more detailed discussion about this literature on the agricultural household model, please refer to the seminal work by Singh et al. (1986). Benjamin (1992) and Jacoby (1993) are two popular empirical applications of agricultural household models in a developing country setting.

${ }^{27} \mathrm{We}$ also control earnings from wage labor and from sales of forest products and find no significant effects
} 


\subsubsection{Access to Agricultural Extension Agency}

Agricultural extension is important for small-scale farmers in rural areas. It helps bridge the gap between research laboratories and agricultural fields to communicate newer information, better farm practices and more efficient managerial skills to farmers (Birkhaeuser et al., 1991). Recent attempts to evaluate the role of extension on agricultural productivity in developing countries find significant and positive effects (Evenson and Mwabu, 2001; Owens et al., 2003; Godtland et al., 2004). However, the returns to investments in extension can vary depending on the context (Anderson and Feder, 2007). Since the knowledge about cash crop cultivation obtained from agricultural extension can also be shared among peers in the same peer group, it is necessary that we also control for potential knowledge spillovers.

To account for the potential spillovers of access to agricultural extension on the profitability level of small-scale farmers, we use two measures of exposure to the services provided by extension; whether a household has ever been in contact with the local extension office $(=1$ if contacted) and frequency of contacts (over the last 12 months).

\section{$6 \quad$ Empirical Results}

\subsection{Validity of Instruments}

We use the observed attributes of friends of friends for instruments: proportion land in cash crops, livestock ownership, number of family members between 15-60 years of age, caste and total land holding. We argue that observed attributes of friends of friends can help influence the average outcome of friends. For example, caste is an important social attribute in the daily lives of people throughout India (Ostrom, 2000). Thus, the caste of one's friends may influence one's outcome.

of these two factors. The reason why we do not report the effects of these two sources of income is that one might be worried that cash crop revenue and incomes earn off-farms could be simultaneously determined, which means that production and consumption decisions of farmers might not be separable (Singh et al., 1986). 
In the context of Thaltukhod Valley, one's caste status could indicate greater access to credit sources, leadership in local governing institutions and market information. If one has friends of friends who have greater access to such information sources, one's friends could also benefit from improved access to information. This effect might be particularly strong for a household which belongs to the lower caste and has friends belonging to the higher caste. Livestock ownership is another component that could also affect the revenue of one's friends. Since livestock can be a useful input in agricultural production, peer farmers might bring their livestock to plow and work on their plots together or farmers might borrow livestock from their friends to work on their land, resulting in information exchange. One could receive advice and information from one's friends through the livestock activities conducted among friends of friends.

[Table 2 around here]

To test the validity of the instrument set, we test for robust pairwise correlation between each instrument (friends of friends' exogenous characteristics) and outcome (cash crop revenue). The results can be found in Table 2. All excluded instruments exhibit significant coefficients. These results provide additional confirmation that the observed attributes of friends of friends are highly correlated with the average of cash crop revenue of friends.

\subsection{Regression Results}

The estimation results in Table 3 illustrate OLS and generalized 2SLS models with robust standard errors. Point estimates of endogenous effects are 0.133 (OLS) and 0.814 (2SLS), both statistically significant. We also estimate both models with network fixed effects. Point estimates for endogenous effects in the OLS and 2SLS models when controlling for network fixed effects are -0.104, which is not significant and not different from zero, and 0.594, which is significant. The increase in coefficient estimates for endogenous effects indicates negative omitted variable bias, suggesting that OLS underestimates endogenous social effect. This 
bias can lead to other biased coefficient estimates of other explanatory variables in the same regression. The point estimates of the endogenous peer effect indicate that a one percentage increase in average cash crop revenue of peers is correlated with an increase a household's cash crop revenue by $0.594 \%$ and $0.814 \%$ according to the 2SLS models with and without network fixed effects (Table 3, Columns 4 and 2).

\section{[Table 3 around here]}

A possible explanation for this negative omitted variable bias could be due to limited resources at the household level. Labor supply is an important element in agricultural productivity in Thaltukhod Valley. However, household labor supply is limited. To mitigate this labor supply constraint, peers share labor actively in all stages of agricultural production. To receive the best possible prices for cash crops, harvest timing is of particular importance. On the other hand, if a group of farmers share labor work on one farm, farms owned by other farmers are left with less labor supply to work on those farms and might not be able to harvest their crops in time to receive the best possible prices.

A farmer's own characteristics and the average of peers' observed attributes appear to significantly affect households' cash crop revenue. The larger the land area a household allocates to growing cash crops, the more livestock a household owns, and the larger the total land holdings, the higher the household's revenue from selling cash crops. On the other hand, the more land allocated by peers to grow cash crop and the greater peers' total land, the lower a farmer's cash crop revenue. These results are consistent with the anecdotal evidence of labor pooling among farmers in Thaltukhod Valley. ${ }^{28}$

\footnotetext{
${ }^{28}$ One might worry that the inclusion of both farmers' and their peers' characteristics in the same regressions might lead to multicollinearity. To check this, we test for variation within factor (VIF) for all specifications and detect that no variable has VIF over 15. This suggests that multicollinearity is not a major problem. For a farmer's own characteristics, significant determinants that lead to greater cash crop revenue include area cultivated, livestock holding, elevation and slope. Farmers who allocate more land area to grow cash crop and own more livestock tend to earn higher revenue from their cash crops. Plots that are located at a higher elevation tend to be larger in size, and plots of higher slope are less favorable to grow crops.
} 
One important issue that arises from the estimation of peer effects is the test statistics associated with generalized 2SLS estimation. When estimating peer effects without controlling for network-specific characteristics (Table 3, Column 2), the Kleibergen-Paap Wald F statistic, which indicates the strength of the instruments, is 7.911. This result is associated with $20 \%-25 \%$ maximal instrumental variable relative bias according to the Stock-Yogo critical values, which provide the threshold for the corresponding level of relative bias from estimates. An implication of this regression is that the construction of the linear-in-means model can lead to biased estimates due to weak instruments with a small sample size. ${ }^{29}$ However, such bias could be mitigated by estimating 2SLS model and controlling for network-specific characteristics (Table 3, Column4). This specification improves the explanatory power of the instrument set significantly. The Kleibergen-Paap Wald F statistic is 10.529, and the relative bias is lower to only between $5 \%-10 \%$. In both models, the p-values of the Hansen $\mathrm{J}$ statistics (which reports likelihood of overidentification) are 0.583 and 0.111 , which indicate that the instrument set does not overidentify the endogenous social effect.

\section{[Table 4 around here]}

Table 4 reports the first-stage predicted average cash crop revenue of peers. The regression results show that almost all instruments except the number of family members aged 15-60 when not controlling for network-specific characteristics and total land ownership have statistically strong explanatory power for the average revenue of peers, a measure of the endogenous social effect. The statistical significance of the instruments helps guarantee that the first-stage regressions could predict the endogenous social effect accurately.

\footnotetext{
${ }^{29}$ This is an issue that does not get discussed in Bramoullé et al. (2009), so it remains to be seen whether there estimation results would also suffer from this issue. Note that the sample size in Bramoullé et al. (2009) from the Add-Health data is 55,208, while there are only 509 households from Thaltukhod Valley in this study.
} 


\subsection{Possible Learning Mechanisms}

While finding positive peer effects is evocative, we would like to uncover the possible learning channels through which peer effects operate. One area where we expect to see evidence of social learning through peers is the use of aggregate inputs. The positive peer effects in cash crop revenue may also include potential peer effects on price information, marketing strategies and the technology use of farmers. ${ }^{30}$ We test for the effects of social learning on the use of aggregate input, and two modern inputs: fertilizer and pesticide.

\section{[Table 5 around here]}

Table 5 presents the regression results for three dependent variables: total expenditures on aggregate input, on fertilizer expenditure and on pesticide expenditure. ${ }^{31}$ We observe significant and positive peer effects on total aggregate input expenditures and on pesticide expenditure, but not on chemical fertilizer expenditure. The absence of significant peer effects on fertilizer use might be due to its cost, high degree of substitution with organic fertilizer such as manure and lack of availability in the local market. The use of pesticide can be dependent on exogenous production shocks such as pest or blight, which could vary from year to year. This leads to an unpredictable nature of pesticide investments among farmers in any given year. Therefore, the collective use of pesticide among peer farmers might be beneficial due to reasons including cost sharing, learning by doing and positive spillovers. Overall, we observe that the effects of peers in input expenditures are stronger (0.803 for aggregate inputs and 0.799 for pesticide, see Table 5, Columns (1) and (3)) than the effects of peers in cash crop revenue (0.594, see Table 3, Column (4)). ${ }^{32}$

\footnotetext{
${ }^{30}$ Ideally, we also would like to test peer effects on price information of Thaltukhod farmers. However, we do not have reliable data about prices of cash crops farmers received to test this hypothesis empirically.

${ }^{31}$ According to our data, approximately $33 \%$ of total aggregate input expenditures belong to fertilizer and $5 \%$ belongs to pesticide.

${ }^{32}$ One could question that the peer effects of expenditures on aggregate input, fertilizer and pesticide could be largely driven by geographical proximity. In another set of regressions (unreported but available upon request), we test for peer effects on input expenditures, on fertilizer expenditure and on pesticide expenditure based on proximity and find no significant peer effects. Therefore, we can conclude that input expenditures among Thaltukhod farmers are not largely driven by geographical proximity.
} 
We also investigate peer effects on the land area allocated to growing cash crops. Since pea is a relatively new crop in the region, we suspect that its cultivation practices might not be yet familiar to all farmers. ${ }^{33}$ Such unfamiliarity with the production process requires learning by doing, which can also be facilitated by learning from peers. Additionally, peas are highly perishable, and need to be delivered to the market at the right time to receive a good price. So, farmers might require strategic information to make sure they can guarantee high price for peas.

\section{[Table 6 around here]}

In Table 6 we use the proportion of land area allocated to growing cash crops by each farmer as the dependent variable using the full sample. We notice significant and positive peer effects on the proportion of land allocated to growing cash crops, especially to peas (0.910). However, we do not observe similar effects on the proportion of land allocated to kidney beans and potatoes. This result is not surprising because kidney beans and potatoes are established crops in the area, which might not require much information from peers. ${ }^{34}$

\section{[Table 7 around here]}

We are interested in finding out whether peer effects might be more prevalent in the productivity of growing a new crop (peas) rather than persistent crops (kidney beans and potatoes). In Table 7, we estimate the total revenue of each crop (in rupees) per land unit (bhiga) using the full sample. The results show that peer effects are positive and significant for peas (0.846) and kidney beans (0.683), but not for potatoes. ${ }^{35}$ The magnitude of peer

\footnotetext{
${ }^{33}$ About $53 \%$ of the farmers in Thaltukhod grow peas in 2008. Peas were introduced and adopted rapidly in the area and the share of farmers growing peas increased only slightly during the past few years preceding the survey.

${ }^{34}$ Conley and Udry (2010) also observe similar outcome where significant peer effects are evident only in a new crop, but not in established crops.

${ }^{35}$ One might worry if the negative but insignificant peer effects on farmers' productivity in potato cultivation might be driving our results. To test this concern, we run the model specification in Table 3, Column 4 again using only potato revenue and find positive effects. Therefore, positive peer effects on potato revenue cannot be driven largely by negative (although insignificant) peer effects on farmers' productivity in potato cultivation.
} 
effects is largest for peas, which is a new crop cultivated in the area and might benefit from information from peers. Potato, on the other hand, is a traditional crop that has long been cultivated in the area, which farmers might not need much information from peers. The results in this table are consistent with the results presented in Table 6 .

Given the fact that the point estimates for the endogenous social effect on input expenditures is higher than that of cash crop revenue (0.803, Table 5, Column 1 and 0.594, Table 3, Column 4), one might be inclined to conclude that the peer effects from input expenditures largely dominates the peer effects on cash crop revenue. However, in terms of magnitude the average cash crop revenue for Thaltukhod farmers is 9,341 rupees whereas the average expenditure on cash input is 2,634 rupees. Therefore, it is unrealistic to claim that the peer effects on cash crop revenue are solely driven by the peer effects on cash input use.

To provide numerical approximations of how much peer effects capture the variation in farmers' cash crop revenue, we multiply the point estimate of the endogenous effect of the cash crop revenue (0.594, Table 3, Column 4) with the average cash crop revenue among Thaltukhod farmers (9,341 rupees), which is 5,548 rupees. Similarly, we multiply the point estimate of the endogenous effect of the cash crop revenue (0.803, Table 5, Column 1) with the average cash crop revenue among Thaltukhod farmers (2,634 rupees), which is 2,110 rupees. In terms of land allocation for growing cash crops and its effect on revenue, we calculate the average effect of land allocation on revenue by multiplying the average cash crop revenue per land unit (577.89 and 1,154.92 rupees per bhiga), the average land area allocated to growing each cash crop (1.308 and 1.626 bhiga), and the point estimates of the endogenous social effect of productivity measure (0.683 and 0.846, Table 7, Columns 1 and 3). ${ }^{36}$ The average peer effects from land allocation on cash crop revenue is approximately 2,105 rupees. Note that this figure is an upper bound since we have not accounted for any opportunity cost associated with using cultivated land for cash crops.

\footnotetext{
${ }^{36}$ In order to make a strong case for this argument, we only calculate the average effect for kidney beans and peas since the coefficient estimate of the endogenous effect for the productivity of potato cultivation is negative.
} 
Combining the two average effects of input expenditures and land allocation, we still observe a considerable difference between farmers' cash crop revenue and combined effect of input expenditures and land allocation of about 1,333 rupees. One might want to conclude this additional portion of revenue might be attributed to returns to input use. However, the rate of returns to input use of 1.63 seems to be too high. Instead, we suspect that the remaining portion of cash crop revenue unexplained by input expenditures and land allocation could be attributed to TFP, which can include peer effects. Overall, these calculations imply that the peer effects on input expenditures and land allocation can only explain $75 \%$ of the peer effects on cash crop revenue at the maximum. Therefore, at least $25 \%$ of farmers' cash crop revenue is left unexplained according to our results.

We can relate our findings to the three possible peer mechanisms outlined in Oster and Thornton (2012). Since we cannot test for each mechanism explicitly and the three mechanisms could exist concurrently, our results provide the net effect of the three learning mechanisms among peer farmers. To provide a comparison whether the outcome of one's peers or one's observed attributes dominate one's own outcome, we test for the joint significance of the coefficient estimates among the observed attributes of one's peers. The test results indicate that the observed attributes of peers are important in determining farmers' cash crop revenue (Table 3, Column 4) and land allocation for cash crops (Table 6, Column 1) together with the outcome of their peers, but not for aggregate input expenditures (Table 5, Column 1). Similar to Conley and Udry (2010), we find that the outcome of peer farmers is important to farmers' input expenditures. With regards to cash crop revenue and land allocation for cash crops, both the outcome of peers and peers' observed attributes are important to one's own outcome.

\subsection{Robustness}

\subsubsection{Test of Confounding Factors}

[Table 8 around here] 
One might question whether our results are driven by a number of possible confounding factors that could affect cash crop revenue; geography, off-farm income opportunities and access to agricultural extension, and that these factors could also be correlated across peers. The results for these tests for confounding factors are reported in Tables 8 and 9. For geography, we account for distance to the main market in Thaltukhod Valley, elevation, and slope. These factors are all statistically insignificant. Most of these coefficient estimates are insignificant except for the interaction term between distance and family members between 15 and 60 of one's peers. However, we test for joint significance of this interaction term and the endogenous social effect do not find enough evidence to conclude that the coefficient estimates for these two variables are jointly significant at the 0.05 level.

[Table 9 around here]

We test for contact with extension (dummy variable) and frequency of visits, and find significant effect of frequency of visits from extension on a farmer's cash crop revenue. Since the frequency of visits from extension has a significant impact on a household's cash crop revenue, we test whether this significance of extension visits is correlated with the average cash crop revenue of peers. We test for the joint significance of parameter estimates for the regression in Table 9 Column 4 and the p-value of the test is 0.0154 , meaning there is not sufficient evidence to claim that peer effects and extension visits are not jointly significant at the 0.05 level. Moreover, we find no effect of peers' contact and frequency of talks with extension agent on farmers' cash crop revenue. Finally, this study uses a cross-sectional dataset. Thus, we cannot capture the dissipation of information over time or other timevarying effects in this study.

\subsubsection{Farmers' Common Characteristics}

In section 5.3.1, we mentioned that we cannot explicitly control for the correlated effects due to any unobserved variation within each network. One concern might be that farmers 
would choose to associate with other farmers who share similar observed attributes. Such attributes can include land ownership, livestock ownership and labor supply.

We perform pair-wise correlation tests which include network-specific fixed effects for all three attributes of interest. The results show that farmers' attributes are not strongly correlated with the attributes of their peers, suggesting this potential concern is not a major problem in our study.

\subsubsection{Top-Coding}

One might be concerned about top-coding, that by this construction of survey questions about personal relationships, we leave out a number of links that households did not get to report. The issue of top-coding could lead to biased estimates of peer effects (Chandrasekhar and Lewis, 2011) due to missing information about social ties. For example, de Weerdt (2002) and Fafchamps and Gubert (2007) report substantial loss of information of personal links. In our dataset, this is not a major concern since more than half of the households reported only a few links per category.

[Table 10 around here]

To deal with this potential problem, in all our specifications we row-normalize the interaction matrix $\boldsymbol{G}$. Further, as a robustness check we run the same model specifications as in Table 3 but restrict the sample to only households who reported to have only two close peers that they consulted for general advice, which consists of $45 \%$ of all the households. The results in Table 10 report evidence of significant and positive peer effects, but the magnitude is smaller than that of the specification with full set of peers. Results suggest that top-coding is not a serious concern in this study.

\subsubsection{Further Instrumentation}

Another concern with identification is that the instrument set, friends of friends' attributes $\boldsymbol{G}^{2} x$, could contain one's own information. This would be the case if an individual 
that Farmer A listed as a peer also listed Farmer A as a friend. To reconcile this concern, we replace the instrument set $\boldsymbol{G}^{2} x$ with the observed attributes of friends of friends of friends, $G^{3} x$ (one further degree of separation). We run all the specifications again in Table 3 and present the results in Table 11. Results remain positive and significant, with slightly lower magnitude when not controlling for network-specific effects and slightly higher estimate when controlling for network-specific effects.

[Table 11 around here]

\subsubsection{Alternative Definitions of Peer Group}

One might worry that our construction of the peer group interaction matrix to estimate peer effects on cash crop revenue might be contingent on the definition of peers in the survey. Since our prior construction of the interaction matrix $\boldsymbol{G}$ takes the union of both peers that a household consults in general and on agricultural matters, we split the two types of peers and estimate their effects separately. ${ }^{37}$

[Table 12 around here]

We estimate Equation (6) again using both peer groups. Peer effects results on cash crop revenue remain positive and significant, as shown in Table 12. Specifically, the point estimate for the endogenous social effect for peers consulted about agricultural matters (0.851) is higher than for peers consulted about general matters (0.647). Thus, when we restrict the sample only to peers listed as sources of agricultural information, we observe a higher point estimate of peer effects. The result suggests that peer effects are likely transmitted more strongly through agricultural peers, not just general peers.

\footnotetext{
${ }^{37}$ Approximately $25 \%$ of the households report that peers who they seek advice from most frequently for general matters are also ones who they seek advice from most frequently particularly for agricultural matters.
} 


\subsubsection{Proximity Effects}

Finally, one might be concerned that the peer effects on cash crop revenue we have identified could be largely driven by geographical proximity. To test for this concern, we alter the definition of one's peers to be one's five nearest neighbors based on geographical distance derived from GPS coordinates, which is the same approach used in Helmers and Patnam (2014)..$^{38}$

[Table 13 around here]

We estimate Equation (6) again with the same specifications in Table 3 and present the results in 13. We find significant endogenous social effect on cash crop revenue using the 2SLS model. However, when controlling for network-level fixed effects, the endogenous geographic effect is not statistically significant anymore. This result confirms that the peer effects we have identified are not mainly driven by geographical proximity.

\section{Conclusion}

In this study, we use social interaction information from all households in Thaltukhod Valley, Himachal Pradesh, India to estimate peer effects on cash crop revenue. Our estimation approach closely follows the method developed by Moffitt (2001), Lee (2007) and empirically illustrated by Bramoullé et al. (2009). We use this approach to separate exogenous and endogenous social effects.

We find evidence of positive and significant peer effects on cash crop revenue. Farmers are more likely to earn higher revenue from selling cash crops if their peers on average earn more from cash crops. Moreover, farmers' observed attributes and those of their peers also have significant effects on cash crop revenue.

\footnotetext{
${ }^{38}$ One might be concerned about the overlap between the members in a farmer's peer group and a farmer's five nearest geographic peers. We run the correlation between the two groups of peers and report the correlation of 0.183 . This suggests that there is only a small overlap between one's social peers and geographic peers among Thaltukhod farmers.
} 
We investigate the possible learning mechanisms through which peer effects might be communicated. We find evidence of learning through increased input expenditure and greater allocation of land to growing a new cash crop. Our results are similar to the results in (Conley and Udry, 2010) and (Munshi, 2004), who find peer effects evident in the use of input and the allocation of land to grow a new crop. We identify positive peer effects for input expenditures, especially for pesticides, but not chemical fertilizer. We also find evidence of peer effects in the cultivation of a recently introduced cash crops but no effect on established crops. These results indicate evidence of social learning among peers. However, peer effects through input expenditures and crop land allocation are unlikely to fully explain increases in revenue from cash crops among peers. Other possible learning mechanisms that can help explain improved cash crop revenue among peers include management, negotiation and marketing skills, although we cannot test for these mechanisms empirically in this study.

We test for a number of confounding factors that could challenge the identification strategy used in this study. Our results also show that the specification of the linear-in-means model according to Bramoullé et al. (2009) can lead to weak instrument problem in small sample sizes. However, this problem can be addressed by removing common unobserved characteristics faced by individuals in the same social network. The network fixed effects may remove the unobserved correlated effects, at least to some degree. The fact that peer effects are strongest for those peers from whom farmers ask for agricultural advice further strengthens our argument that we have captured peer effects and not other factors that are common to farmers' general network. 


\section{References}

Abdulai, A. and Huffman, W. E. (2005). The diffusion of new agricultural technologies: The case of crossbred-cow technology in Tanzania. American Journal of Agricultural Economics, 87(3):645-659.

Aker, J. C. (2010). Information from markets near and far: Mobile phones and agricultural markets in Niger. American Economic Journal: Applied Economics, 2(3):46-59.

Anderson, J. R. and Feder, G. (2007). Agricultural extension. In Evenson, R. and Pingali, P., editors, Agricultural Development: Farmers, Farm Production and Farm Markets, volume 3 of Handbook of Agricultural Economics, chapter 44, pages 2343 - 2378. Elsevier.

Bandiera, O. and Rasul, I. (2006). Social networks and technology adoption in Northern Mozambique. Economic Journal, 116(514):869-902.

Banerjee, A., Chandrasekhar, A. G., Duflo, E., and Jackson, M. O. (2013). The diffusion of microfinance. Science, 341(6144).

Barrett, C. B., Clark, M. B., Clay, D. C., and Reardon, T. (2005). Heterogeneous constraints, incentives and income diversification strategies in rural Africa. Quarterly journal of international agriculture, 44(1):37-60.

Bartel, A., Ichniowski, C., and Shaw, K. (2007). How does information technology affect productivity? Plant-level comparisons of product innovation, process improvement, and worker skills. Quarterly Journal of Economics, 122(4):1721-1758.

Bell, K. P. and Dalton, T. J. (2007). Spatial economic analysis in data-rich environments. Journal of Agricultural Economics, 58(3):487-501.

Benjamin, D. (1992). Household composition, labor markets, and labor demand: Testing for separation in agricultural household models. Econometrica, 60(2):287-322. 
Bertrand, M. and Schoar, A. (2003). Managing with style: The effect of managers on firm policies. Quarterly Journal of Economics, pages 1169-1208.

Besley, T. and Case, A. (1994). Diffusion as a learning process: Evidence from HYV cotton. Working Papers 228, Princeton University, Woodrow Wilson School of Public and International Affairs, Research Program in Development Studies.

Birkhaeuser, D., Evenson, R. E., and Feder, G. (1991). The economic impact of agricultural extension: A review. Economic Development and Cultural Change, 39(3):607-650.

Black, S. E. and Lynch, L. M. (2001). How to compete: The impact of workplace practices and information technology on productivity. Review of Economics and statistics, 83(3):434-445.

Bloom, N., Eifert, B., Mahajan, A., McKenzie, D., and Roberts, J. (2013). Does management matter? Evidence from India. Quarterly Journal of Economics, 128(1):1-51.

Bloom, N., Genakos, C., Martin, R., and Sadun, R. (2010). Modern management: Good for the environment or just hot air? Economic Journal, 120(544):551-572.

Bramoullé, Y., Djebbari, H., and Fortin, B. (2009). Identification of peer effects through social networks. Journal of Econometrics, 150(1):41-55.

Brock, W. A. and Durlauf, S. N. (2001). Interactions-based models. In Heckman, J. and Leamer, E., editors, Handbook of Econometrics, volume 5 of Handbook of Econometrics, chapter 54, pages 3297-3380. Elsevier.

Carrell, S. E., Fullerton, R. L., and West, J. E. (2009). Does your cohort matter? Measuring peer effects in college achievement. Journal of Labor Economics, 27(3):439-464.

Chandrasekhar, A. G. and Lewis, R. (2011). Econometrics of sampled networks.

Conley, T. G. and Udry, C. R. (2010). Learning about a new technology: Pineapple in Ghana. American Economic Review, 100(1):35-69. 
de Janvry, A. and Sadoulet, E. (2006). Progress in the modeling of rural households behavior under market failures. In de Janvry, A. and Kanbur, R., editors, Poverty, Inequality and Development, volume 1 of Economic Studies in Inequality, Social Exclusion and WellBeing, pages 155-181. Springer US.

de Weerdt, J. (2002). Risk-sharing and endogenous network formation. Number 2002/57. WIDER Discussion Papers. World Institute for Development Economics (UNU-WIDER).

de Weerdt, J. and Dercon, S. (2006). Risk-sharing networks and insurance against illness. Journal of Development Economics, 81(2):337-356.

de Weerdt, J. and Fafchamps, M. (2011). Social identity and the formation of health insurance networks. Journal of Development Studies, 47(8):1152-1177.

Duflo, E., Dupas, P., and Kremer, M. (2011). Peer effects, teacher incentives, and the impact of tracking: Evidence from a randomized evaluation in Kenya. American Economic Review, 101(5):1739-74.

Duflo, E., Kremer, M., and Robinson, J. (2008). How high are rates of return to fertilizer? Evidence from field experiments in Kenya. American Economic Review, 98(2):482-88.

Durlauf, S. N. and Fafchamps, M. (2005). Social Capital. In Aghion, P. and Durlauf, S., editors, Handbook of Economic Growth, volume 1 of Handbook of Economic Growth, chapter 26, pages 1639-1699. Elsevier.

Evenson, R. E. and Mwabu, G. (2001). The effect of agricultural extension on farm yields in Kenya. African Development Review, 13(1):1 - 23.

Fafchamps, M. and Gubert, F. (2007). The formation of risk sharing networks. Journal of Development Economics, 83(2):326-350.

Fafchamps, M. and Shilpi, F. (2003). The spatial division of labour in Nepal. Journal of Development Studies, 39(6):23-66. 
Fan, S., Hazell, P., and Thorat, S. (2000). Government spending, growth and poverty in rural India. American Journal of Agricultural Economics, 82(4):1038-1051.

Feder, G., Just, R. E., and Zilberman, D. (1985). Adoption of Agricultural Innovations in Developing Countries: A Survey. Economic Development and Cultural Change, 33(2):25598.

Foster, A. D. and Rosenzweig, M. R. (1995). Learning by doing and learning from others: Human capital and technical change in agriculture. Journal of Political Economy, 103(6):1176-1209.

Foster, G. (2006). It's not your peers, and it's not your friends: Some progress toward understanding the educational peer effect mechanism. Journal of Public Economics, 90(89):1455 $-1475$.

Genius, M., Koundouri, P., Nauges, C., and Tzouvelekas, V. (2014). Information transmission in irrigation technology adoption and diffusion: Social learning, extension services, and spatial effects. American Journal of Agricultural Economics, 96(1):328-344.

Giorgi, G. D., Pellizzari, M., and Redaelli, S. (2010). Identification of social interactions through partially overlapping peer groups. American Economic Journal: Applied Economics, 2(2):241-75.

Godtland, E. M., Sadoulet, E., de Janvry, A., Murgai, R., and Ortiz, O. (2004). The impact of farmer field schools on knowledge and productivity: A study of potato farmers in the Peruvian Andes. Economic Development and Cultural Change, 53(1):63-92.

Goyal, A. (2010). Information, direct access to farmers, and rural market performance in Central India. American Economic Journal: Applied Economics, 2(3):22-45.

Helmers, C. and Patnam, M. (2014). Does the rotten child spoil his companion? Spatial peer effects among children in rural India. Quantitative Economics, 5(1):67-121. 
Holloway, G., Shankar, B., and Rahman, S. (2002). Bayesian spatial probit estimation: A primer and an application to HYV rice adoption. Agricultural Economics, 27(3):383-402.

Ichinowski, C., Shaw, K., and Prennushi, G. (1997). The effects of human resource management practices on productivity: A study of steel finishing lines. American Economic Review, 87(3):291-313.

Jacoby, H. G. (1993). Shadow wages and peasant family labour supply: An econometric application to the Peruvian Sierra. Review of Economic Studies, 60(4):903-21.

Jain, T. and Kapoor, M. (2014). The impact of study groups and roommates on academic performance. Review of Economics and Statistics, (0).

Jensen, R. (2007). The digital provide: Information (technology), market performance, and welfare in the South Indian fisheries sector. Quarterly Journal of Economics, 122(3):879924.

Kelejian, H. H. and Prucha, I. R. (1998). A generalized spatial two-stage least squares procedure for estimating a spatial autoregressive model with autoregressive disturbances. Journal of Real Estate Finance and Economics, 17(1):99-121.

Kremer, M. and Miguel, E. (2007). The illusion of sustainability. Quarterly Journal of Economics, 122(3):1007-1065.

Langyintuo, A. S. and Mekuria, M. (2008). Assessing the influence of neighborhood effects on the adoption of improved agricultural technologies in developing agriculture. African Journal of Agricultural and Resource Economics, 2(2).

Lee, L. (2007). Identification and estimation of econometric models with group interactions, contextual factors and fixed effects. Journal of Econometrics, 140(2):333-374.

Lin, X. (2010). Identifying peer effects in student academic achievement by spatial autoregressive models with group unobservables. Journal of Labor Economics, 28(4):825-860. 
Liverpool-Tasie, L. S. O. and Winter-Nelson, A. (2012). Social learning and farm technology in ethiopia: Impacts by technology, network type, and poverty status. Journal of Development Studies, 48(10):1505-1521.

Lyle, D. S. (2007). Estimating and interpreting peer and role model effects from randomly assigned social groups at West Point. The Review of Economics and Statistics, 89(2):289299.

Maertens, A. and Barrett, C. B. (2013). Measuring social networks' effects on agricultural technology adoption. American Journal of Agricultural Economics, 95(2):353-359.

Manski, C. F. (1993). Identification of endogenous social effects: The reflection problem. Review of Economic Studies, 60(3):531-42.

Moffitt, R. A. (2001). Policy interventions, low-level equilibria, and social interactions. In Durlauf, S. N. and Young, H. P., editors, Social Dynamics, pages 45-82. MIT Press.

Munshi, K. (2003). Networks in the modern economy: Mexican migrants in the U.S. labor market. Quarterly Journal of Economics, 118(2):549-599.

Munshi, K. (2004). Social learning in a heterogeneous population: Technology diffusion in the Indian Green Revolution. Journal of Development Economics, 73(1):185-213.

Murgai, R., Ali, M., and Byerlee, D. (2001). Productivity growth and sustainability in postGreen Revolution agriculture: The case of the Indian and Pakistan Punjabs. The World Bank Research Observer, 16(2):199-218.

Oster, E. and Thornton, R. (2012). Determinants of technology adoption: Peer effects in menstrual cup take-up. Journal of the European Economic Association, 10(6):1263-1293.

Ostrom, E. (2000). Collective action and the evolution of social norms. Journal of Economic Perspectives, 14(3):137-158. 
Owens, T., Hoddinott, J., and Kinsey, B. (2003). The impact of agricultural extension on farm production in resettlement areas of Zimbabwe. Economic Development and Cultural Change, 51(2):337-357.

Pattanayak, S. K. and Butry, D. T. (2005). Spatial complementarity of forests and farms: Accounting for ecosystem services. American Journal of Agricultural Economics, 87(4):9951008.

Ruttan, V. W. (2002). Productivity growth in world agriculture: Sources and constraints. The Journal of Economic Perspectives, 16(4):pp. 161-184.

Sacerdote, B. (2001). Peer effects with random assignment: Results for Dartmouth roommates. Quarterly Journal of Economics, 116(2):681-704.

Sarmiento, C. and Wilson, W. W. (2008). Spatial competition and ethanol plant location decisions. 2008 Annual Meeting, July 27-29, 2008, Orlando, Florida 6175, American Agricultural Economics Association.

Singh, I., Squire, L., Strauss, J., and Bank, W. (1986). Agricultural Household Models: Extensions, Applications, and Policy. World Bank Research Publication. Johns Hopkins University Press.

van den Broeck, K. and Dercon, S. (2011). Information flows and social externalities in a Tanzanian banana growing village. Journal of Development Studies, 47(2):231-252.

van Rijn, F., Bulte, E., and Adekunle, A. (2012). Social capital and agricultural innovation in Sub-Saharan Africa. Agricultural Systems, 108:112-122.

Wooldridge, J. M. (2010). Econometric Analysis of Cross Section and Panel Data. Number 0262232588 in MIT Press Books. The MIT Press.

Zimmerman, D. J. (2003). Peer effects in academic outcomes: Evidence from a natural experiment. Review of Economics and Statistics, 85(1):9-23. 
Table 1: Summary statistics

\begin{tabular}{lccccc}
\hline \hline \multicolumn{1}{c}{ Variable } & $\mathrm{N}$ & Mean & SD & Min. & Max. \\
\hline Family size (persons) & 509 & 5.719 & 2.348 & 1 & 17 \\
Family members 0-14 years (persons) & 509 & 1.758 & 1.532 & 0 & 8 \\
Family members 15-60 years (persons) & 509 & 3.608 & 1.8 & 0 & 10 \\
Family members above 60 years (persons) & 509 & 0.350 & 0.633 & 0 & 3 \\
Education at least 8 years (\% of family members) & 509 & 0.400 & 0.251 & 0 & 1 \\
Caste (=1 if high caste) & 509 & 0.851 & 0.357 & 0 & 1 \\
Land holding (bhiga) & 509 & 8.192 & 6.131 & 0.5 & 50 \\
Cash crop land (\% of total land) & 509 & 0.505 & 0.181 & 0.148 & 1 \\
Livestock ownership (units) & 509 & 0.576 & 1.014 & 0 & 13 \\
Distance to main trading location (Euclidean unit) & 509 & 0.017 & 0.012 & 0.001 & 0.445 \\
Elevation (meters above mean sea level) & 509 & 2007.13 & 220.06 & 1323.67 & 2518.39 \\
Slope (degrees) & 509 & 26.16 & 5.19 & 12.00 & 39.83 \\
Distance to the nearest bus stop (Euclidean unit) & 509 & 0.032 & 0.015 & 0.010 & 0.068 \\
Labor income (rupees) & 509 & 3111.75 & 3267.058 & 0 & 25000 \\
Forest income (rupees) & 509 & 140.08 & 1367.99 & 0 & 26000 \\
Contact with extension (=1 if yes) & 509 & 0.984 & 0.125 & 0 & 1 \\
Frequency of talks with extension (previous 12 months) & 509 & 5.07 & 2.44 & 0 & 24 \\
Cash crop revenue (rupees) & 509 & 9341.65 & 7372.29 & 500 & 95400 \\
Cash input expenditure (rupees) & 509 & 2634.46 & 2193.252 & 200 & 31200 \\
Fertilizer expenditure (rupees) & 509 & 683.30 & 729.86 & 0 & 15000 \\
Pesticide expenditure (rupees) & 509 & 194.40 & 461.21 & 0 & 8000 \\
\hline \hline
\end{tabular}


Table 2: Instrument Robustness Support

\begin{tabular}{lc}
\hline \hline \multicolumn{1}{c}{ Instruments } & Test statistics \\
\hline Robust pairwise correlation & \\
Proportion of cash crop land & $0.391^{* * *}$ \\
Livestock & $0.278^{* * *}$ \\
Family members 15-60 years & $-0.076^{* *}$ \\
Caste & $0.974^{* * *}$ \\
Total land holding & $0.055^{* * *}$ \\
\hline \hline
\end{tabular}

${ }^{*} p<0.1,{ }^{* *} p<0.05,{ }^{* * *} p<0.01$ 
Table 3: Peer Effects Estimates of Cash Crop Revenue (rupees)

\begin{tabular}{|c|c|c|c|c|}
\hline & $\begin{array}{c}(1) \\
\text { Revenue } \\
\text { OLS }\end{array}$ & $\begin{array}{c}(2) \\
\text { Revenue } \\
2 \text { SLS }\end{array}$ & $\begin{array}{c}(3) \\
\text { Revenue } \\
\text { OLS }\end{array}$ & $\begin{array}{c}(4) \\
\text { Revenue } \\
2 \text { SLS }\end{array}$ \\
\hline $\begin{array}{l}\text { Endogenous social effects } \\
\text { Endogenous effect }\end{array}$ & $\begin{array}{c}0.133^{*} \\
(0.075)\end{array}$ & $\begin{array}{l}0.814^{* *} \\
(0.316)\end{array}$ & $\begin{array}{c}-0.104 \\
(0.089)\end{array}$ & $\begin{array}{l}0.594^{* *} \\
(0.286)\end{array}$ \\
\hline $\begin{array}{l}\text { Own characteristics } \\
\text { Proportion of cash crop land }\end{array}$ & $\begin{array}{c}0.688^{* * *} \\
(0.239)\end{array}$ & $\begin{array}{c}1.059^{* * *} \\
(0.323)\end{array}$ & $\begin{array}{l}0.548^{*} \\
(0.289)\end{array}$ & $\begin{array}{l}0.824^{* *} \\
(0.339)\end{array}$ \\
\hline Livestock & $\begin{array}{l}0.091^{* *} \\
(0.036)\end{array}$ & $\begin{array}{l}0.080^{* *} \\
(0.033)\end{array}$ & $\begin{array}{l}0.091^{* *} \\
(0.045)\end{array}$ & $\begin{array}{l}0.083^{* *} \\
(0.035)\end{array}$ \\
\hline Family members $15-60$ years & $\begin{array}{c}0.010 \\
(0.011)\end{array}$ & $\begin{array}{c}0.011 \\
(0.012)\end{array}$ & $\begin{array}{c}0.013 \\
(0.012)\end{array}$ & $\begin{array}{c}0.012 \\
(0.012)\end{array}$ \\
\hline Caste & $\begin{array}{c}0.005 \\
(0.185)\end{array}$ & $\begin{array}{c}0.003 \\
(0.235)\end{array}$ & $\begin{array}{c}0.029 \\
(0.177)\end{array}$ & $\begin{array}{c}0.026 \\
(0.211)\end{array}$ \\
\hline Total land holding & $\begin{array}{c}0.061^{* * *} \\
(0.006)\end{array}$ & $\begin{array}{c}0.060^{* * *} \\
(0.006)\end{array}$ & $\begin{array}{c}0.060^{* * *} \\
(0.006)\end{array}$ & $\begin{array}{c}0.060^{* * *} \\
(0.007)\end{array}$ \\
\hline $\begin{array}{l}\text { Exogenous social effects } \\
\text { Proportion of cash crop land }\end{array}$ & $\begin{array}{l}-0.046 \\
(0.252)\end{array}$ & $\begin{array}{l}-0.879^{*} \\
(0.470)\end{array}$ & $\begin{array}{c}0.456 \\
(0.296)\end{array}$ & $\begin{array}{l}-0.393 \\
(0.453)\end{array}$ \\
\hline Livestock & $\begin{array}{l}0.069^{* *} \\
(0.033)\end{array}$ & $\begin{array}{l}-0.110 \\
(0.091)\end{array}$ & $\begin{array}{c}0.119^{* * *} \\
(0.040)\end{array}$ & $\begin{array}{l}-0.061 \\
(0.084)\end{array}$ \\
\hline Family members $15-60$ years & $\begin{array}{l}-0.020 \\
(0.018)\end{array}$ & $\begin{array}{c}-0.026 \\
(0.022)\end{array}$ & $\begin{array}{l}-0.019 \\
(0.020)\end{array}$ & $\begin{array}{l}-0.021 \\
(0.023)\end{array}$ \\
\hline Caste & $\begin{array}{c}0.541^{* * *} \\
(0.191)\end{array}$ & $\begin{array}{c}0.159 \\
(0.319)\end{array}$ & $\begin{array}{c}0.669^{* * *} \\
(0.189)\end{array}$ & $\begin{array}{c}0.337 \\
(0.278)\end{array}$ \\
\hline Total land holding & $\begin{array}{c}-0.011^{* *} \\
(0.005)\end{array}$ & $\begin{array}{c}-0.045^{* * *} \\
(0.017)\end{array}$ & $\begin{array}{c}0.001 \\
(0.006)\end{array}$ & $\begin{array}{c}-0.036^{* *} \\
(0.017)\end{array}$ \\
\hline Network FE & - & - & Yes & Yes \\
\hline Test statistics & & & & \\
\hline Kleibergen-Paap Wald F statistic & - & 7.911 & - & 10.529 \\
\hline Hansen J statistic & - & 0.301 & - & 6.006 \\
\hline Hansen p-value & - & 0.583 & - & 0.111 \\
\hline Observations & 509 & 509 & 509 & 509 \\
\hline
\end{tabular}


Table 4: First-stage Estimates of Endogenous Social Effects

\begin{tabular}{|c|c|c|}
\hline & $\begin{array}{c}\text { (1) } \\
\text { Endog. Effects } \\
\text { OLS }\end{array}$ & $\begin{array}{c}(2) \\
\text { Endog. Effects } \\
\text { OLS }\end{array}$ \\
\hline $\begin{array}{l}\text { Own characteristics } \\
\text { Proportion of cash crop land }\end{array}$ & $\begin{array}{r}-0.295^{*} \\
(0.163)\end{array}$ & $\begin{array}{l}-0.137 \\
(0.143)\end{array}$ \\
\hline Caste & $\begin{array}{l}-0.096 \\
(0.233)\end{array}$ & $\begin{array}{l}-0.096 \\
(0.181)\end{array}$ \\
\hline Livestock & $\begin{array}{l}-0.007 \\
(0.013)\end{array}$ & $\begin{array}{l}-0.009 \\
(0.012)\end{array}$ \\
\hline Family members $15-60$ years & $\begin{array}{c}0.001 \\
(0.008)\end{array}$ & $\begin{array}{c}0.005 \\
(0.006)\end{array}$ \\
\hline Total land holding & $\begin{array}{c}0.003 \\
(0.002)\end{array}$ & $\begin{array}{c}0.001 \\
(0.001)\end{array}$ \\
\hline $\begin{array}{l}\text { Included instruments } \\
\text { Proportion of cash crop land }\end{array}$ & $\begin{array}{c}1.607^{* * *} \\
(0.240)\end{array}$ & $\begin{array}{c}1.494^{* * *} \\
(0.197)\end{array}$ \\
\hline Caste & $\begin{array}{l}-0.175 \\
(0.437)\end{array}$ & $\begin{array}{l}-0.215 \\
(0.293)\end{array}$ \\
\hline Livestock & $\begin{array}{c}0.203^{* * *} \\
(0.027)\end{array}$ & $\begin{array}{c}0.221^{* * *} \\
(0.029)\end{array}$ \\
\hline Family members $15-60$ years & $\begin{array}{c}0.017 \\
(0.018)\end{array}$ & $\begin{array}{c}0.011 \\
(0.016)\end{array}$ \\
\hline Total land holding & $\begin{array}{c}0.054^{* * *} \\
(0.006)\end{array}$ & $\begin{array}{c}0.0556^{* * *} \\
(0.005)\end{array}$ \\
\hline $\begin{array}{l}\text { Excluded instruments } \\
\text { Proportion of cash crop land }\end{array}$ & $\begin{array}{c}-0.599^{* *} \\
(0.245)\end{array}$ & $\begin{array}{c}-1.243^{* * *} \\
(0.326)\end{array}$ \\
\hline Caste & $\begin{array}{l}0.899^{* *} \\
(0.373)\end{array}$ & $\begin{array}{c}0.773^{* * *} \\
(0.258)\end{array}$ \\
\hline Livestock & $\begin{array}{l}0.123^{* *} \\
(0.038)\end{array}$ & $\begin{array}{c}0.183^{* * *} \\
(0.040)\end{array}$ \\
\hline Family members $15-60$ years & $\begin{array}{l}-0.005 \\
(0.025)\end{array}$ & $\begin{array}{c}-0.048^{* *} \\
(0.024)\end{array}$ \\
\hline Total land holding & $\begin{array}{c}-0.011^{* *} \\
(0.005)\end{array}$ & $\begin{array}{l}-0.010 \\
(0.007)\end{array}$ \\
\hline Network FE & - & Yes \\
\hline $\begin{array}{l}\text { Test statistics } \\
\text { R-square } \\
\text { Observations }\end{array}$ & $\begin{array}{c}0.723 \\
509\end{array}$ & $\begin{array}{c}0.813 \\
509\end{array}$ \\
\hline
\end{tabular}

Standard errors in parentheses

${ }^{*} p<0.1,{ }^{* *} p<0.05,{ }^{* * *} p<0.01$ 
Table 5: Learning Mechanism: Estimates of Input Expenditures (rupees)

\begin{tabular}{|c|c|c|c|}
\hline & $\begin{array}{c}(1) \\
\text { Expenditures } \\
\text { Cash Inputs } \\
\text { 2SLS }\end{array}$ & $\begin{array}{c}(2) \\
\text { Expenditures } \\
\text { Fertilizer } \\
\text { 2SLS }\end{array}$ & $\begin{array}{c}(3) \\
\text { Expenditures } \\
\text { Pesticide } \\
\text { 2SLS }\end{array}$ \\
\hline $\begin{array}{l}\text { Endogenous social effects } \\
\text { Endogenous effect }\end{array}$ & $\begin{array}{l}0.803^{* *} \\
(0.363)\end{array}$ & $\begin{array}{l}-0.430 \\
(0.183)\end{array}$ & $\begin{array}{c}0.799^{* * *} \\
(0.192)\end{array}$ \\
\hline $\begin{array}{l}\text { Own characteristics } \\
\text { Proportion of cash crop land }\end{array}$ & $\begin{array}{l}0.369^{*} \\
(0.219)\end{array}$ & $\begin{array}{c}0.255 \\
(0.248)\end{array}$ & $\begin{array}{l}3.220^{* *} \\
(1.510)\end{array}$ \\
\hline Livestock & $\begin{array}{l}0.0470 \\
(0.030)\end{array}$ & $\begin{array}{c}-0.0320 \\
(0.80)\end{array}$ & $\begin{array}{c}0.335 \\
(0.246)\end{array}$ \\
\hline Family members $15-60$ years & $\begin{array}{c}0.0323^{* *} \\
(0.014)\end{array}$ & $\begin{array}{l}0.0572^{*} \\
(0.030)\end{array}$ & $\begin{array}{c}0.145 \\
(0.104)\end{array}$ \\
\hline Caste & $\begin{array}{l}0.870^{*} \\
(0.474)\end{array}$ & $\begin{array}{l}-0.244 \\
(0.355)\end{array}$ & $\begin{array}{l}-1.523 \\
(1.189)\end{array}$ \\
\hline Total land holding & $\begin{array}{l}0.0280^{* * *} \\
(0.005)\end{array}$ & $\begin{array}{l}0.0402^{* * *} \\
(0.007)\end{array}$ & $\begin{array}{c}0.0812^{* * *} \\
(0.025)\end{array}$ \\
\hline $\begin{array}{l}\text { Exogenous social effects } \\
\text { Proportion of cash crop land }\end{array}$ & $\begin{array}{l}-0.195 \\
(0.331)\end{array}$ & $\begin{array}{r}-0.0287 \\
(0.349)\end{array}$ & $\begin{array}{c}-5.010^{* * *} \\
(1.528)\end{array}$ \\
\hline Livestock & $\begin{array}{r}-0.0620 \\
(0.071)\end{array}$ & $\begin{array}{l}0.435^{* *} \\
(0.195)\end{array}$ & $\begin{array}{l}-0.351 \\
(0.510)\end{array}$ \\
\hline Family members $15-60$ years & $\begin{array}{l}-0.0109 \\
(0.036)\end{array}$ & $\begin{array}{l}0.0418 \\
(0.095)\end{array}$ & $\begin{array}{l}0.0300 \\
(0.152)\end{array}$ \\
\hline Caste & $\begin{array}{r}-0.821 \\
(0.56)\end{array}$ & $\begin{array}{c}0.705 \\
(0.587)\end{array}$ & $\begin{array}{c}0.547 \\
(1.116)\end{array}$ \\
\hline Total land holding & $\begin{array}{c}-0.0158^{*} \\
(0.009)\end{array}$ & $\begin{array}{c}0.00141 \\
(0.013)\end{array}$ & $\begin{array}{c}-0.115^{* * *} \\
(0.037)\end{array}$ \\
\hline Network FE & Yes & Yes & Yes \\
\hline Test statistics & & & \\
\hline Kleibergen-Paap Wald F-statistic & 4.465 & 6.728 & 14.045 \\
\hline Hansen J statistic & 1.246 & 1.353 & 2.236 \\
\hline Hansen p-value & 0.871 & 0.245 & 0.327 \\
\hline Observations & 504 & 504 & 504 \\
\hline
\end{tabular}

Standard errors in parentheses

${ }^{*} p<0.1,{ }^{* *} p<0.05,{ }^{* * *} p<0.01$ 
Table 6: Learning Mechanism: Proportion of Cash Crop Land

\begin{tabular}{|c|c|c|c|c|}
\hline & $\begin{array}{c}(1) \\
\text { Allocation } \\
\text { Total Land } \\
\text { 2SLS }\end{array}$ & $\begin{array}{c}(2) \\
\text { Allocation } \\
\text { Kidney Bean Land } \\
\text { 2SLS }\end{array}$ & $\begin{array}{c}(3) \\
\text { Allocation } \\
\text { Potato Land } \\
\text { 2SLS }\end{array}$ & $\begin{array}{c}(4) \\
\text { Allocation } \\
\text { Pea Land } \\
\text { 2SLS }\end{array}$ \\
\hline $\begin{array}{l}\text { Endogenous social effects } \\
\text { Endogenous effect }\end{array}$ & $\begin{array}{l}0.809^{*} \\
(0.475)\end{array}$ & $\begin{array}{c}0.740 \\
(0.484)\end{array}$ & $\begin{array}{c}0.895 \\
(0.734)\end{array}$ & $\begin{array}{l}0.910^{*} \\
(0.287)\end{array}$ \\
\hline Own characteristics & & & & \\
\hline Livestock & $\begin{array}{r}0.00457 \\
(0.007)\end{array}$ & $\begin{array}{c}0.00232 \\
(0.003)\end{array}$ & $\begin{array}{c}0.00704 \\
(0.005)\end{array}$ & $\begin{array}{c}-0.00169 \\
(0.005)\end{array}$ \\
\hline Family members $15-60$ years & $\begin{array}{c}-0.000982 \\
(0.003)\end{array}$ & $\begin{array}{c}-0.00113 \\
(0.001)\end{array}$ & $\begin{array}{c}-0.00117 \\
(0.002)\end{array}$ & $\begin{array}{c}0.00290 \\
(0.002)\end{array}$ \\
\hline Caste & $\begin{array}{l}0.0288 \\
(0.044)\end{array}$ & $\begin{array}{c}-0.00326 \\
(0.011)\end{array}$ & $\begin{array}{c}-0.0431^{*} \\
(0.019)\end{array}$ & $\begin{array}{l}0.0514 \\
(0.030)\end{array}$ \\
\hline Total land holding & $\begin{array}{l}-0.00441^{* * *} \\
\quad(0.002)\end{array}$ & $\begin{array}{c}-0.00120^{* *} \\
(0.0004)\end{array}$ & $\begin{array}{r}-0.00170^{*} \\
(0.0007)\end{array}$ & $\begin{array}{l}-0.000032 \\
(0.001)\end{array}$ \\
\hline Exogenous social effects & & & & \\
\hline Livestock & $\begin{array}{r}0.00387 \\
(0.016)\end{array}$ & $\begin{array}{c}-0.000845 \\
(0.008)\end{array}$ & $\begin{array}{c}-0.00192 \\
(0.007)\end{array}$ & $\begin{array}{c}0.00809 \\
(0.009)\end{array}$ \\
\hline Family members $15-60$ years & $\begin{array}{c}0.00518 \\
(0.006)\end{array}$ & $\begin{array}{c}0.00633 \\
(0.004)\end{array}$ & $\begin{array}{c}0.000548 \\
(0.003)\end{array}$ & $\begin{array}{c}-0.00343 \\
(0.003)\end{array}$ \\
\hline Caste & $\begin{array}{c}-0.0793^{* * *} \\
(0.030)\end{array}$ & $\begin{array}{c}-0.00579 \\
(0.016)\end{array}$ & $\begin{array}{l}0.0283 \\
(0.068)\end{array}$ & $\begin{array}{l}-0.0512 \\
(0.033)\end{array}$ \\
\hline Total land holding & $\begin{array}{c}0.0107^{* *} \\
(0.006)\end{array}$ & $\begin{array}{c}-0.000556 \\
(0.001)\end{array}$ & $\begin{array}{c}0.00124 \\
(0.001)\end{array}$ & $\begin{array}{c}0.00194 \\
(0.001)\end{array}$ \\
\hline Network FE & Yes & Yes & Yes & Yes \\
\hline Test statistics & & & & \\
\hline Kleibergen-Paap Wald F-statistic & 3.665 & 4.196 & 1.073 & 22.799 \\
\hline Hansen J statistic & 1.054 & 0.037 & 0.003 & 1.208 \\
\hline Hansen p-value & 0.305 & 0.847 & 0.955 & 0.547 \\
\hline$N$ & 509 & 509 & 509 & 509 \\
\hline
\end{tabular}


Table 7: Learning Mechanism: Productivity Measure (Revenue per land unit)

\begin{tabular}{|c|c|c|c|}
\hline & $\begin{array}{c}(1) \\
\text { Productivity } \\
\text { Kidney Beans } \\
\text { 2SLS }\end{array}$ & $\begin{array}{c}(2) \\
\text { Productivity } \\
\text { Potatoes } \\
\text { 2SLS }\end{array}$ & $\begin{array}{c}(3) \\
\text { Productivity } \\
\text { Peas } \\
\text { 2SLS }\end{array}$ \\
\hline \multicolumn{4}{|l|}{ Endogenous social effects } \\
\hline Endogenous effect & $\begin{array}{c}0.683^{* * *} \\
(0.113)\end{array}$ & $\begin{array}{l}-0.625 \\
(0.619)\end{array}$ & $\begin{array}{l}0.846^{*} \\
(0.456)\end{array}$ \\
\hline \multicolumn{4}{|l|}{ Own characteristics } \\
\hline Proportion of cash crop land & $\begin{array}{l}-348.2 \\
(658.9)\end{array}$ & $\begin{array}{c}-6091.9^{* * *} \\
(1697.5)\end{array}$ & $\begin{array}{l}-2452.5 \\
(2538.7)\end{array}$ \\
\hline Livestock & $\begin{array}{l}-41.38 \\
(26.95)\end{array}$ & $\begin{array}{c}20.25 \\
(52.01)\end{array}$ & $\begin{array}{c}2175.5 \\
(1342.1)\end{array}$ \\
\hline Family members $15-60$ years & $\begin{array}{c}4.427 \\
(12.15)\end{array}$ & $\begin{array}{c}26.26 \\
(27.85)\end{array}$ & $\begin{array}{l}-162.5 \\
(152.9)\end{array}$ \\
\hline Caste & $\begin{array}{l}139.3^{* *} \\
(63.15)\end{array}$ & $\begin{array}{l}-128.5 \\
(605.2)\end{array}$ & $\begin{array}{c}717.5 \\
(781.8)\end{array}$ \\
\hline Total land holding & $\begin{array}{c}-21.24^{* * *} \\
(5.336)\end{array}$ & $\begin{array}{c}-51.56^{* * *} \\
(12.03)\end{array}$ & $\begin{array}{l}-6.361 \\
(22.41)\end{array}$ \\
\hline \multicolumn{4}{|l|}{ Exogenous social effects } \\
\hline Proportion of cash crop land & $\begin{array}{l}-194.1 \\
(975.8)\end{array}$ & $\begin{array}{l}-402.0 \\
(500.8)\end{array}$ & $\begin{array}{c}7063.4 \\
(6818.2)\end{array}$ \\
\hline Livestock & $\begin{array}{c}219.9^{* * *} \\
(76.00)\end{array}$ & $\begin{array}{c}39.17 \\
(117.4)\end{array}$ & $\begin{array}{l}-2814.1 \\
(1628.8)\end{array}$ \\
\hline Family members $15-60$ years & $\begin{array}{c}-70.32^{* * *} \\
(26.80)\end{array}$ & $\begin{array}{l}-0.500 \\
(54.76)\end{array}$ & $\begin{array}{l}452.7^{*} \\
(271.0)\end{array}$ \\
\hline Caste & $\begin{array}{c}58.26 \\
(101.8)\end{array}$ & $\begin{array}{c}1120.3^{* *} \\
(460.5)\end{array}$ & $\begin{array}{l}-702.3 \\
(1038.3)\end{array}$ \\
\hline Total land holding & $\begin{array}{l}-4.118 \\
(5.956)\end{array}$ & $\begin{array}{l}-36.87^{*} \\
(21.94)\end{array}$ & $\begin{array}{c}53.03 \\
(44.65)\end{array}$ \\
\hline Network FE & Yes & Yes & Yes \\
\hline \multicolumn{4}{|l|}{ Test statistics } \\
\hline Kleibergen-Paap Wald F-statistic & 18.387 & 1.204 & 4.549 \\
\hline Hansen J statistic & 4.394 & 4.508 & 1.559 \\
\hline Hansen p-value & 0.222 & 0.212 & 0.459 \\
\hline Observations & 509 & 509 & 509 \\
\hline
\end{tabular}

Standard errors in parentheses

${ }^{*} p<0.1,{ }^{* *} p<0.05,{ }^{* * *} p<0.01$ 
Table 8: Tests of Confounding Effects: Estimates of Cash Crop Revenue (rupees)

\begin{tabular}{|c|c|c|c|c|}
\hline & $\begin{array}{c}(1) \\
\text { Revenue } \\
\text { 2SLS }\end{array}$ & $\begin{array}{c}(2) \\
\text { Revenue } \\
\text { 2SLS }\end{array}$ & $\begin{array}{c}(3) \\
\text { Revenue } \\
\text { 2SLS }\end{array}$ & $\begin{array}{c}(4) \\
\text { Revenue } \\
\text { 2SLS }\end{array}$ \\
\hline $\begin{array}{l}\text { Endogenous social effects } \\
\text { Endogenous effect }\end{array}$ & $\begin{array}{l}0.579^{* *} \\
(0.267)\end{array}$ & $\begin{array}{r}0.565^{* *} \\
(0.281)\end{array}$ & $\begin{array}{r}0.527^{* *} \\
(0.263)\end{array}$ & $\begin{array}{c}0.622^{* *} \\
(0.284)\end{array}$ \\
\hline $\begin{array}{l}\text { Own characteristics } \\
\text { Proportion of cash crop land }\end{array}$ & $\begin{array}{c}0.657^{* * *} \\
(0.095)\end{array}$ & $\begin{array}{c}0.658^{* * *} \\
(0.096)\end{array}$ & $\begin{array}{c}0.664^{* * *} \\
(0.093)\end{array}$ & $\begin{array}{c}0.657^{* * *} \\
(0.096)\end{array}$ \\
\hline Livestock & $\begin{array}{c}0.0852^{* * *} \\
(0.032)\end{array}$ & $\begin{array}{c}0.0851^{* *} \\
(0.033)\end{array}$ & $\begin{array}{c}0.0840^{* *} \\
(0.034)\end{array}$ & $\begin{array}{c}0.0827^{* *} \\
(0.033)\end{array}$ \\
\hline Family members $15-60$ years & $\begin{array}{l}0.0191 \\
(0.012)\end{array}$ & $\begin{array}{l}0.0174 \\
(0.012)\end{array}$ & $\begin{array}{l}0.0190 \\
(0.012)\end{array}$ & $\begin{array}{l}0.0188 \\
(0.013)\end{array}$ \\
\hline Caste & $\begin{array}{l}0.00667 \\
(0.212)\end{array}$ & $\begin{array}{l}0.0505 \\
(0.217)\end{array}$ & $\begin{array}{l}0.0724 \\
(0.216)\end{array}$ & $\begin{array}{l}0.0078 \\
(0.218)\end{array}$ \\
\hline Total land holding & $\begin{array}{l}0.0424^{* * *} \\
(0.011)\end{array}$ & $\begin{array}{c}0.0424^{* * *} \\
(0.011)\end{array}$ & $\begin{array}{c}0.0425^{* * *} \\
(0.011)\end{array}$ & $\begin{array}{c}0.0423^{* * *} \\
(0.011)\end{array}$ \\
\hline Distance to market & $\begin{array}{l}-32.49 \\
(33.03)\end{array}$ & & & \\
\hline Elevation & & $\begin{array}{c}0.000366 \\
(0.0003)\end{array}$ & & \\
\hline Slope & & & $\begin{array}{l}-0.0120 \\
(0.00855)\end{array}$ & \\
\hline Distance to bus stop & & & & $\begin{array}{c}21.55 \\
(32.01)\end{array}$ \\
\hline $\begin{array}{l}\text { Exogenous social effects } \\
\text { Proportion of cash crop land }\end{array}$ & $\begin{array}{c}-0.480^{* *} \\
(0.188)\end{array}$ & $\begin{array}{l}-0.449^{*} \\
(0.237)\end{array}$ & $\begin{array}{r}-0.402^{* *} \\
(0.185)\end{array}$ & $\begin{array}{c}-0.551^{* * *} \\
(0.178)\end{array}$ \\
\hline Livestock & $\begin{array}{r}-0.0386 \\
(0.081)\end{array}$ & $\begin{array}{r}-0.0337 \\
(0.083)\end{array}$ & $\begin{array}{r}-0.0283 \\
(0.081)\end{array}$ & $\begin{array}{c}-0.0583 \\
(0.081)\end{array}$ \\
\hline Family members $15-60$ years & $\begin{array}{r}-0.0188 \\
(0.021)\end{array}$ & $\begin{array}{r}-0.0167 \\
(0.021)\end{array}$ & $\begin{array}{r}-0.0143 \\
(0.020)\end{array}$ & $\begin{array}{r}-0.0160 \\
(0.021)\end{array}$ \\
\hline Caste & $\begin{array}{c}0.351 \\
(0.278)\end{array}$ & $\begin{array}{c}0.315 \\
(0.285)\end{array}$ & $\begin{array}{c}0.322 \\
(0.275)\end{array}$ & $\begin{array}{c}0.295 \\
(0.286)\end{array}$ \\
\hline Total land holding & $\begin{array}{c}-0.0327^{* *} \\
(0.014)\end{array}$ & $\begin{array}{c}-0.0322^{* *} \\
(0.015)\end{array}$ & $\begin{array}{c}-0.0290^{* *} \\
(0.013)\end{array}$ & $\begin{array}{c}-0.0346^{* *} \\
(0.015)\end{array}$ \\
\hline Distance to market & $\begin{array}{c}33.92 \\
(33.13)\end{array}$ & & & \\
\hline Elevation & & $\begin{array}{c}-0.000344 \\
(0.0003)\end{array}$ & & \\
\hline Slope & & & $\begin{array}{c}0.00756 \\
(0.010)\end{array}$ & \\
\hline Distance to bus stop & & & & $\begin{array}{l}-18.76 \\
(32.33)\end{array}$ \\
\hline Test statistics & & & & \\
\hline Kleibergen-Paap Wald F statistic & 8.710 & 8.510 & 9.363 & 7.885 \\
\hline Hansen J statistic & 3.91 & 5.166 & 5.53 & 4.323 \\
\hline Hansen p-value & 0.563 & 0.396 & 0.355 & 0.504 \\
\hline Observations & 510 & 510 & 510 & 510 \\
\hline
\end{tabular}

Standard errors in parentheses

${ }^{*} p<0.1,{ }^{* *} p<0.05,{ }^{* * *} p<0.01$ 
Table 9: Tests of Confounding Effects: Estimates of Cash Crop Revenue (rupees)

\begin{tabular}{|c|c|c|c|}
\hline & $\begin{array}{c}(1) \\
\text { Revenue } \\
\text { 2SLS }\end{array}$ & $\begin{array}{c}(2) \\
\text { Revenue } \\
\text { 2SLS }\end{array}$ & $\begin{array}{c}(3) \\
\text { Revenue } \\
\text { 2SLS }\end{array}$ \\
\hline $\begin{array}{l}\text { Endogenous social effects } \\
\text { Endogenous effect }\end{array}$ & $\begin{array}{c}0.711^{* *} \\
(0.291)\end{array}$ & $\begin{array}{c}0.679^{* *} \\
(0.294)\end{array}$ & $\begin{array}{c}0.727^{* *} \\
(0.322)\end{array}$ \\
\hline $\begin{array}{l}\text { Own characteristics } \\
\text { Proportion of cash crop land }\end{array}$ & $\begin{array}{c}0.952^{* * *} \\
(0.328)\end{array}$ & $\begin{array}{c}0.683^{* * *} \\
(0.105)\end{array}$ & $\begin{array}{c}0.648^{* * *} \\
(0.106)\end{array}$ \\
\hline Livestock & $\begin{array}{c}0.0867^{* * *} \\
(0.034)\end{array}$ & $\begin{array}{c}0.0828^{* *} \\
(0.033)\end{array}$ & $\begin{array}{c}0.0823^{* *} \\
(0.033)\end{array}$ \\
\hline Family members $15-60$ years & $\begin{array}{l}0.0177 \\
(0.039)\end{array}$ & $\begin{array}{l}0.0186 \\
(0.013)\end{array}$ & $\begin{array}{l}0.0133 \\
(0.013)\end{array}$ \\
\hline Caste & $\begin{array}{r}-0.0468 \\
(0.215)\end{array}$ & $\begin{array}{l}0.0485 \\
(0.227)\end{array}$ & $\begin{array}{l}0.0978 \\
(0.238)\end{array}$ \\
\hline Total land holding & $\begin{array}{c}0.0599^{* * *} \\
(0.006)\end{array}$ & $\begin{array}{c}0.0423^{* * *} \\
(0.011)\end{array}$ & $\begin{array}{c}0.0420^{* * *} \\
(0.011)\end{array}$ \\
\hline Distance to bus stop & $\begin{array}{c}22.929 \\
(31.529)\end{array}$ & & \\
\hline Distance to bus stop x Family members $15-60$ years & $\begin{array}{c}-0.206 \\
(1.096)\end{array}$ & & \\
\hline Contact with extension & & $\begin{array}{l}0.0279 \\
(0.102)\end{array}$ & \\
\hline Frequency of talks with extension & & & $\begin{array}{c}0.0244^{* *} \\
(0.010)\end{array}$ \\
\hline $\begin{array}{l}\text { Exogenous social effects } \\
\text { Proportion of cash crop land }\end{array}$ & $\begin{array}{r}-0.798^{*} \\
(0.406)\end{array}$ & $\begin{array}{c}-0.517^{* *} \\
(0.207)\end{array}$ & $\begin{array}{c}-0.483^{* *} \\
(0.219)\end{array}$ \\
\hline Livestock & $\begin{array}{r}-0.0866 \\
(0.076)\end{array}$ & $\begin{array}{r}-0.0637 \\
(0.088)\end{array}$ & $\begin{array}{r}-0.0807 \\
(0.094)\end{array}$ \\
\hline Family members $15-60$ years & $\begin{array}{c}-0.1456^{* *} \\
(0.066)\end{array}$ & $\begin{array}{r}-0.0193 \\
(0.021)\end{array}$ & $\begin{array}{r}-0.0186 \\
(0.022)\end{array}$ \\
\hline Caste & $\begin{array}{c}0.242 \\
(0.283)\end{array}$ & $\begin{array}{c}0.254 \\
(0.302)\end{array}$ & $\begin{array}{c}0.173 \\
(0.329)\end{array}$ \\
\hline Total land holding & $\begin{array}{c}-0.0395^{* *} \\
(0.016)\end{array}$ & $\begin{array}{l}-0.0371^{* *} \\
(0.015)\end{array}$ & $\begin{array}{c}-0.0382^{* *} \\
(0.016)\end{array}$ \\
\hline Distance to bus stop & $\begin{array}{l}-34.728 \\
(31.328)\end{array}$ & & \\
\hline Distance to bus stop x Family members $15-60$ years & $\begin{array}{c}3.914^{* *} \\
(1.830)\end{array}$ & & \\
\hline Contact with extension & & $\begin{array}{l}-0.203 \\
(0.247)\end{array}$ & \\
\hline Frequency of talks with extension & & & $\begin{array}{c}-0.00999 \\
(0.014) \\
\end{array}$ \\
\hline Test statistics & & & \\
\hline Kleibergen-Paap Wald F statistic & 5.543 & 7.796 & 7.005 \\
\hline Hansen J statistic & 1.702 & 3.205 & 2.947 \\
\hline Hansen p-value & 0.889 & 0.668 & 0.708 \\
\hline Observations & 510 & 510 & 510 \\
\hline
\end{tabular}

Standard errors in parentheses

${ }^{*} p<0.1,{ }^{* *} p<0.05,{ }^{* * *} p<0.01$ 
Table 10: Top-Coding: Estimates of Cash Crop Revenue (rupees)

\begin{tabular}{|c|c|c|}
\hline & $\begin{array}{c}(1) \\
\text { Revenue } \\
\text { OLS }\end{array}$ & $\begin{array}{c}(2) \\
\text { Revenue } \\
\text { 2SLS }\end{array}$ \\
\hline $\begin{array}{l}\text { Endogenous social effects } \\
\text { Endogenous effect }\end{array}$ & $\begin{array}{c}0.169^{*} \\
(0.0911)\end{array}$ & $\begin{array}{l}0.542^{*} \\
(0.250)\end{array}$ \\
\hline $\begin{array}{l}\text { Own characteristics } \\
\text { Proportion of cash crop land }\end{array}$ & $\begin{array}{l}0.517^{*} \\
(0.314)\end{array}$ & $\begin{array}{l}0.772^{*} \\
(0.397)\end{array}$ \\
\hline Caste & $\begin{array}{l}0.505^{* * *} \\
(0.0750)\end{array}$ & $\begin{array}{l}0.494^{* * *} \\
(0.0730)\end{array}$ \\
\hline Livestock & $\begin{array}{c}0.0345 \\
(0.0263)\end{array}$ & $\begin{array}{c}0.0312 \\
(0.0248)\end{array}$ \\
\hline Family members $15-60$ years & $\begin{array}{l}0.0199^{*} \\
(0.0116)\end{array}$ & $\begin{array}{l}0.0236^{*} \\
(0.0124)\end{array}$ \\
\hline Total land holding & $\begin{array}{l}0.0589^{* * *} \\
(0.00831)\end{array}$ & $\begin{array}{l}0.0574^{* * *} \\
(0.00915)\end{array}$ \\
\hline $\begin{array}{l}\text { Exogenous social effects } \\
\text { Proportion of cash crop land }\end{array}$ & $\begin{array}{l}-0.165 \\
(0.328)\end{array}$ & $\begin{array}{l}-0.635 \\
(0.494)\end{array}$ \\
\hline Livestock & $\begin{array}{l}0.0815^{*} \\
(0.0464)\end{array}$ & $\begin{array}{l}-0.0114 \\
(0.0787)\end{array}$ \\
\hline Caste & $\begin{array}{l}0.0913 \\
(0.128)\end{array}$ & $\begin{array}{l}-0.107 \\
(0.164)\end{array}$ \\
\hline Family members $15-60$ years & $\begin{array}{l}-0.0284 \\
(0.0221)\end{array}$ & $\begin{array}{l}-0.0399^{*} \\
(0.0223)\end{array}$ \\
\hline Total land holding & $\begin{array}{l}-0.00778 \\
(0.00605)\end{array}$ & $\begin{array}{l}-0.0255^{*} \\
(0.0141)\end{array}$ \\
\hline Test statistics & & \\
\hline Kleibergen-Paap Wald F-statistic & - & 9.027 \\
\hline $\begin{array}{l}\text { Hansen J statistic } \\
\text { Hansen p-value }\end{array}$ & - & $\begin{array}{l}6.426 \\
0.170\end{array}$ \\
\hline Observations & 283 & 283 \\
\hline
\end{tabular}


Table 11: Further Instrumentation: Estimates of Cash Crop Revenue (rupees)

\begin{tabular}{|c|c|c|c|c|}
\hline & $\begin{array}{c}(1) \\
\text { Revenue } \\
\text { OLS }\end{array}$ & $\begin{array}{c}(2) \\
\text { Revenue } \\
2 \text { SLS }\end{array}$ & $\begin{array}{c}(3) \\
\text { Revenue } \\
\text { OLS }\end{array}$ & $\begin{array}{c}(4) \\
\text { Revenue } \\
2 \text { SLS }\end{array}$ \\
\hline $\begin{array}{l}\text { Endogenous social effects } \\
\text { Endogenous effect }\end{array}$ & $\begin{array}{l}0.133^{*} \\
(0.075)\end{array}$ & $\begin{array}{l}0.655^{* *} \\
(0.283)\end{array}$ & $\begin{array}{l}-0.104 \\
(0.089)\end{array}$ & $\begin{array}{c}0.686^{* * *} \\
(0.259)\end{array}$ \\
\hline $\begin{array}{l}\text { Own characteristics } \\
\text { Proportion of cash crop land }\end{array}$ & $\begin{array}{c}0.688^{* * *} \\
(0.239)\end{array}$ & $\begin{array}{c}0.972^{* * *} \\
(0.296)\end{array}$ & $\begin{array}{l}0.548^{*} \\
(0.289)\end{array}$ & $\begin{array}{c}0.861^{* * *} \\
(0.329)\end{array}$ \\
\hline Livestock & $\begin{array}{l}0.091^{* *} \\
(0.036)\end{array}$ & $\begin{array}{l}0.080^{* *} \\
(0.033)\end{array}$ & $\begin{array}{l}0.091^{* *} \\
(0.045)\end{array}$ & $\begin{array}{l}0.083^{* *} \\
(0.035)\end{array}$ \\
\hline Family members $15-60$ years & $\begin{array}{c}0.010 \\
(0.011)\end{array}$ & $\begin{array}{c}0.010 \\
(0.011)\end{array}$ & $\begin{array}{c}0.013 \\
(0.012)\end{array}$ & $\begin{array}{c}0.012 \\
(0.012)\end{array}$ \\
\hline Caste & $\begin{array}{c}0.006 \\
(0.185)\end{array}$ & $\begin{array}{c}0.004 \\
(0.213)\end{array}$ & $\begin{array}{c}0.029 \\
(0.177)\end{array}$ & $\begin{array}{c}0.025 \\
(0.223)\end{array}$ \\
\hline Total land holding & $\begin{array}{c}0.061^{* * *} \\
(0.006)\end{array}$ & $\begin{array}{c}0.060^{* * *} \\
(0.006)\end{array}$ & $\begin{array}{c}0.060^{* * *} \\
(0.006)\end{array}$ & $\begin{array}{c}0.060^{* * *} \\
(0.007)\end{array}$ \\
\hline $\begin{array}{l}\text { Exogenous social effects } \\
\text { Proportion of cash crop land }\end{array}$ & $\begin{array}{l}-0.046 \\
(0.252)\end{array}$ & $\begin{array}{l}-0.684 \\
(0.423)\end{array}$ & $\begin{array}{c}0.456 \\
(0.296)\end{array}$ & $\begin{array}{l}-0.505 \\
(0.423)\end{array}$ \\
\hline Livestock & $\begin{array}{c}0.069^{* *} \\
(0.033)\end{array}$ & $\begin{array}{l}-0.068 \\
(0.080)\end{array}$ & $\begin{array}{c}0.119^{* * *} \\
(0.040)\end{array}$ & $\begin{array}{l}-0.085 \\
(0.075)\end{array}$ \\
\hline Family members $15-60$ years & $\begin{array}{l}-0.020 \\
(0.018)\end{array}$ & $\begin{array}{l}-0.025 \\
(0.020)\end{array}$ & $\begin{array}{c}-0.019 \\
(0.020)\end{array}$ & $\begin{array}{l}-0.021 \\
(0.024)\end{array}$ \\
\hline Caste & $\begin{array}{c}0.541^{* * *} \\
(0.191)\end{array}$ & $\begin{array}{c}0.248 \\
(0.281)\end{array}$ & $\begin{array}{c}0.669^{* * *} \\
(0.189)\end{array}$ & $\begin{array}{c}0.293 \\
(0.285)\end{array}$ \\
\hline Total land holding & $\begin{array}{c}-0.011^{* *} \\
(0.005)\end{array}$ & $\begin{array}{c}-0.037^{* *} \\
(0.015)\end{array}$ & $\begin{array}{c}0.001 \\
(0.006)\end{array}$ & $\begin{array}{c}-0.040^{* * *} \\
(0.015)\end{array}$ \\
\hline Network FE & - & - & Yes & Yes \\
\hline Test statistics & & & & \\
\hline Kleibergen-Paap Wald F statistic & - & 6.224 & - & 12.085 \\
\hline Hansen J statistic & - & 3.125 & - & 3.162 \\
\hline Hansen p-value & - & 0.373 & - & 0.367 \\
\hline Observations & 509 & 509 & 509 & 509 \\
\hline
\end{tabular}


Table 12: Alternative Definitions of Peers: Estimates of Cash Crop Revenue (rupees)

\begin{tabular}{|c|c|c|}
\hline & $\begin{array}{c}(1) \\
\text { Revenue } \\
2 \text { SLS } \\
\end{array}$ & $\begin{array}{c}(2) \\
\text { Revenue } \\
2 \text { SLS } \\
\end{array}$ \\
\hline $\begin{array}{l}\text { Endogenous social effects } \\
\text { Endogenous effect }\end{array}$ & $\begin{array}{l}0.647^{* *} \\
(0.310)\end{array}$ & $\begin{array}{l}0.851^{*} \\
(0.441)\end{array}$ \\
\hline $\begin{array}{l}\text { Own characteristics } \\
\text { Proportion of cash crop land }\end{array}$ & $\begin{array}{c}0.775^{* * *} \\
(0.258)\end{array}$ & $\begin{array}{c}0.890^{* * *} \\
(0.286)\end{array}$ \\
\hline Livestock & $\begin{array}{c}0.0871^{* *} \\
(0.036)\end{array}$ & $\begin{array}{c}0.0923^{* * *} \\
(0.035)\end{array}$ \\
\hline Family members $15-60$ years & $\begin{array}{l}0.0186 \\
(0.012)\end{array}$ & $\begin{array}{l}0.0109 \\
(0.016)\end{array}$ \\
\hline Caste & $\begin{array}{l}0.337^{*} \\
(0.177)\end{array}$ & $\begin{array}{l}0.429^{* *} \\
(0.188)\end{array}$ \\
\hline Total land holding & $\begin{array}{c}0.0421^{* * *} \\
(0.011)\end{array}$ & $\begin{array}{c}0.0417^{* * *} \\
(0.011)\end{array}$ \\
\hline $\begin{array}{l}\text { Exogenous social effects } \\
\text { Proportion of cash crop land }\end{array}$ & $\begin{array}{l}-0.295 \\
(0.279)\end{array}$ & $\begin{array}{c}-0.772^{* *} \\
(0.369)\end{array}$ \\
\hline Livestock & $\begin{array}{r}-0.0640 \\
(0.068)\end{array}$ & $\begin{array}{r}-0.0538 \\
(0.088)\end{array}$ \\
\hline Family members 15 - 60 years & $\begin{array}{c}-0.0354^{* *} \\
(0.017)\end{array}$ & $\begin{array}{l}-0.0251 \\
(0.020)\end{array}$ \\
\hline Caste & $\begin{array}{l}0.0297 \\
(0.252)\end{array}$ & $\begin{array}{l}-0.234 \\
(0.369)\end{array}$ \\
\hline Total land holding & $\begin{array}{c}-0.0180^{*} \\
(0.010)\end{array}$ & $\begin{array}{c}-0.0268^{* *} \\
(0.014)\end{array}$ \\
\hline Network FE & Yes & Yes \\
\hline Test statistics & & \\
\hline Kleibergen-Paap Wald F statistic & 3.679 & 4.867 \\
\hline Hansen J statistic & 0.335 & 2.256 \\
\hline Hansen p-value & 0.988 & 0.133 \\
\hline Observations & 508 & 504 \\
\hline
\end{tabular}


Table 13: Proximity Effects Estimates of Cash Crop Revenue (rupees)

\begin{tabular}{|c|c|c|c|c|}
\hline & $\begin{array}{c}(1) \\
\text { Revenue } \\
\text { OLS }\end{array}$ & $\begin{array}{c}(2) \\
\text { Revenue } \\
2 \text { SLS } \\
\end{array}$ & $\begin{array}{c}(3) \\
\text { Revenue } \\
\text { OLS }\end{array}$ & $\begin{array}{c}(4) \\
\text { Revenue } \\
2 \text { SLS }\end{array}$ \\
\hline \multicolumn{5}{|l|}{ Endogenous social effects } \\
\hline Endogenous effect & $\begin{array}{c}0.137 \\
(0.084)\end{array}$ & $\begin{array}{c}0.524^{* *} \\
(0.219)\end{array}$ & $\begin{array}{l}-0.139 \\
(0.099)\end{array}$ & $\begin{array}{c}0.375 \\
(0.275)\end{array}$ \\
\hline \multicolumn{5}{|l|}{ Own characteristics } \\
\hline Proportion of cash crop land & $\begin{array}{c}0.922^{* * *} \\
(0.176)\end{array}$ & $\begin{array}{c}1.030^{* * *} \\
(0.191)\end{array}$ & $\begin{array}{c}0.911^{* * *} \\
(0.298)\end{array}$ & $\begin{array}{c}0.952^{* * *} \\
(0.297)\end{array}$ \\
\hline Livestock & $\begin{array}{l}0.100^{* *} \\
(0.040)\end{array}$ & $\begin{array}{l}0.094^{* *} \\
(0.041)\end{array}$ & $\begin{array}{c}0.096^{* *} \\
(0.043)\end{array}$ & $\begin{array}{l}0.100^{* *} \\
(0.045)\end{array}$ \\
\hline Family members $15-60$ years & $\begin{array}{c}0.019 \\
(0.013)\end{array}$ & $\begin{array}{c}0.022 \\
(0.013)\end{array}$ & $\begin{array}{c}0.021 \\
(0.013)\end{array}$ & $\begin{array}{l}0.022^{*} \\
(0.012)\end{array}$ \\
\hline Caste & $\begin{array}{c}0.772^{* * *} \\
(0.129)\end{array}$ & $\begin{array}{c}0.769^{* * *} \\
(0.131)\end{array}$ & $\begin{array}{c}0.778^{* * *} \\
(0.139)\end{array}$ & $\begin{array}{c}0.784^{* * *} \\
(0.141)\end{array}$ \\
\hline Total land holding & $\begin{array}{c}0.043^{* * *} \\
(0.011)\end{array}$ & $\begin{array}{c}0.043^{* * *} \\
(0.011)\end{array}$ & $\begin{array}{c}0.042^{* * *} \\
(0.010)\end{array}$ & $\begin{array}{c}0.043^{* * *} \\
(0.010)\end{array}$ \\
\hline \multicolumn{5}{|l|}{ Exogenous social effects } \\
\hline Proportion of cash crop land & $\begin{array}{c}-0.404^{* *} \\
(0.186)\end{array}$ & $\begin{array}{c}-0.632^{\text {*** }} \\
(0.226)\end{array}$ & $\begin{array}{c}-0.069 \\
(0.219)\end{array}$ & $\begin{array}{l}-0.382 \\
(0.284)\end{array}$ \\
\hline Livestock & $\begin{array}{c}0.040 \\
(0.043)\end{array}$ & $\begin{array}{l}-0.065 \\
(0.072)\end{array}$ & $\begin{array}{c}0.079 \\
(0.054)\end{array}$ & $\begin{array}{l}-0.023 \\
(0.074)\end{array}$ \\
\hline Family members $15-60$ years & $\begin{array}{c}-0.078^{* * *} \\
(0.023)\end{array}$ & $\begin{array}{c}-0.057^{* *} \\
(0.027)\end{array}$ & $\begin{array}{c}-0.079^{* * *} \\
(0.022)\end{array}$ & $\begin{array}{c}-0.061^{* *} \\
(0.026)\end{array}$ \\
\hline Caste & $\begin{array}{c}-0.245^{*} \\
(0.136)\end{array}$ & $\begin{array}{c}-0.449^{* * *} \\
(0.165)\end{array}$ & $\begin{array}{l}-0.070 \\
(0.142)\end{array}$ & $\begin{array}{c}-0.332^{*} \\
(0.193)\end{array}$ \\
\hline Total land holding & $\begin{array}{c}-0.001 \\
(0.008)\end{array}$ & $\begin{array}{l}-0.025 \\
(0.015)\end{array}$ & $\begin{array}{c}0.007 \\
(0.008)\end{array}$ & $\begin{array}{c}-0.024 \\
(0.018)\end{array}$ \\
\hline Network FE & - & - & Yes & Yes \\
\hline Test statistics & & & & \\
\hline Kleibergen-Paap Wald F statistic & - & 15.060 & - & 12.153 \\
\hline Hansen J statistic & - & 4.142 & - & 4.200 \\
\hline Hansen p-value & - & 0.387 & - & 0.380 \\
\hline Observations & 509 & 509 & 509 & 509 \\
\hline
\end{tabular}




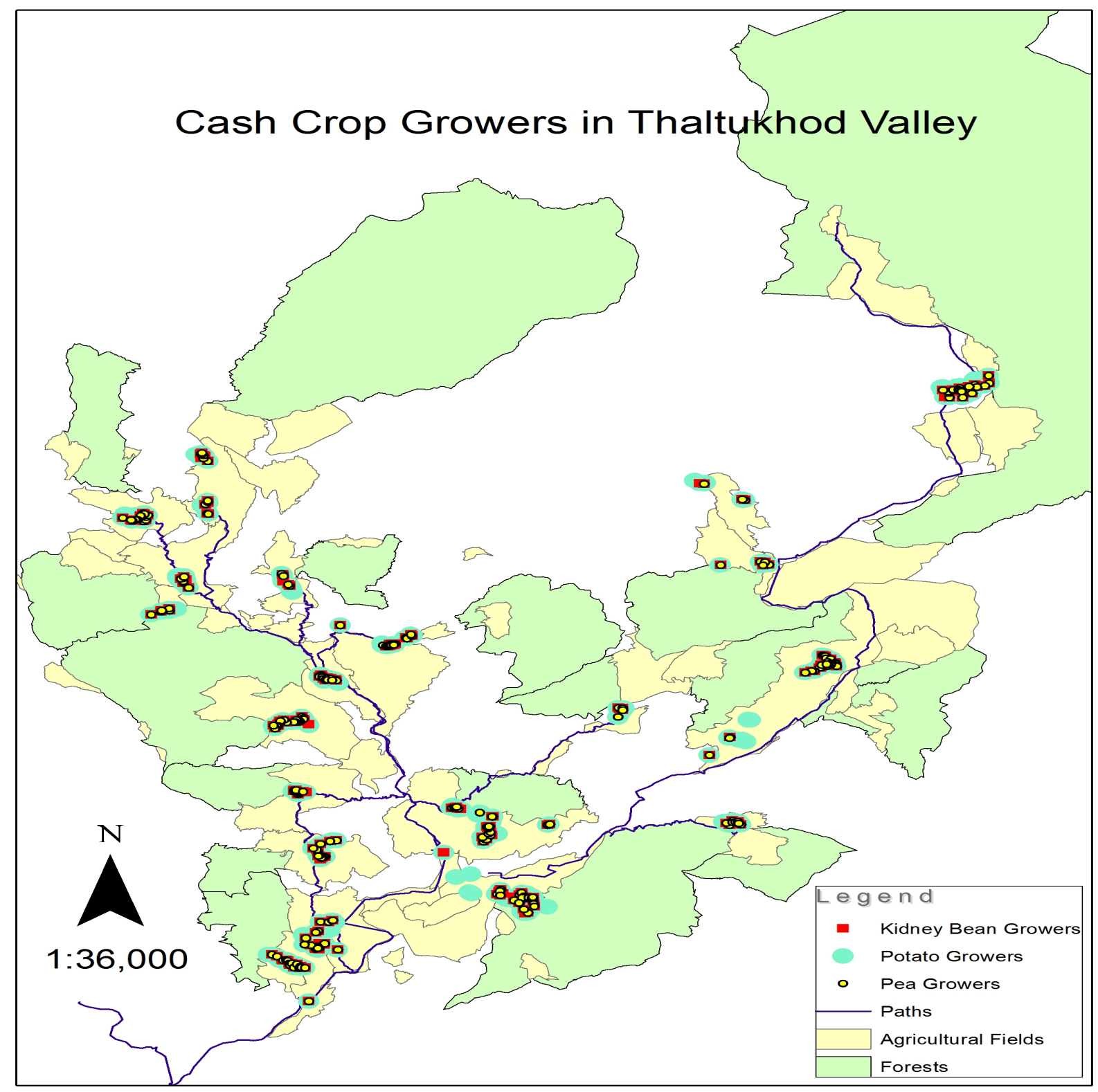

Figure 1: Production Locations of Cash Crops in Thaltukhod Valley. 


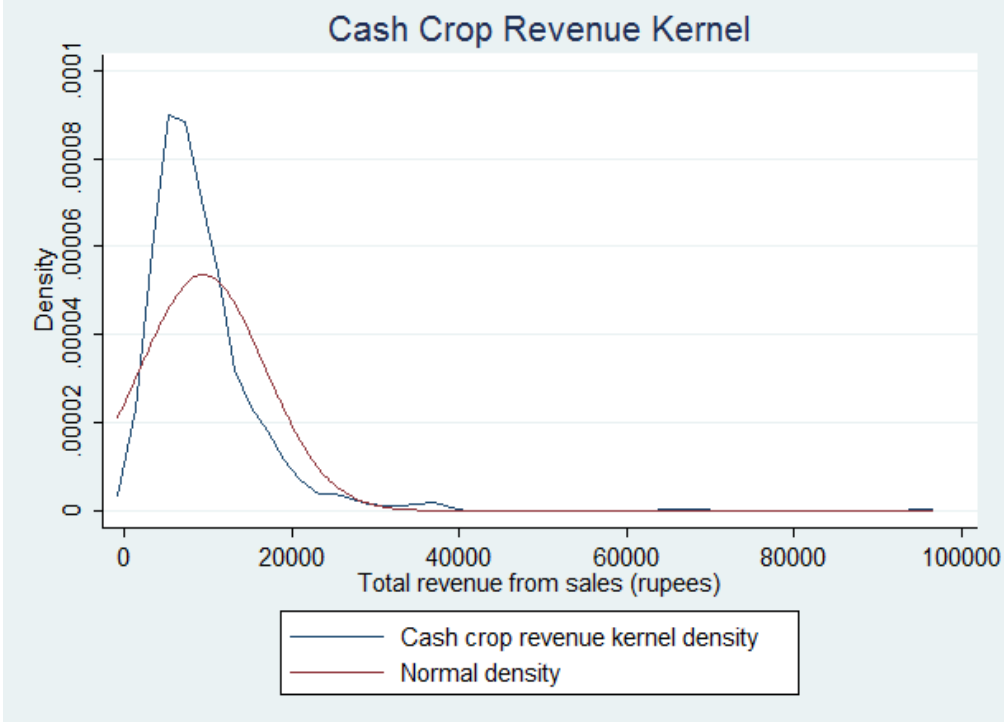

Figure 2: Cash Crop Revenue Kernel.

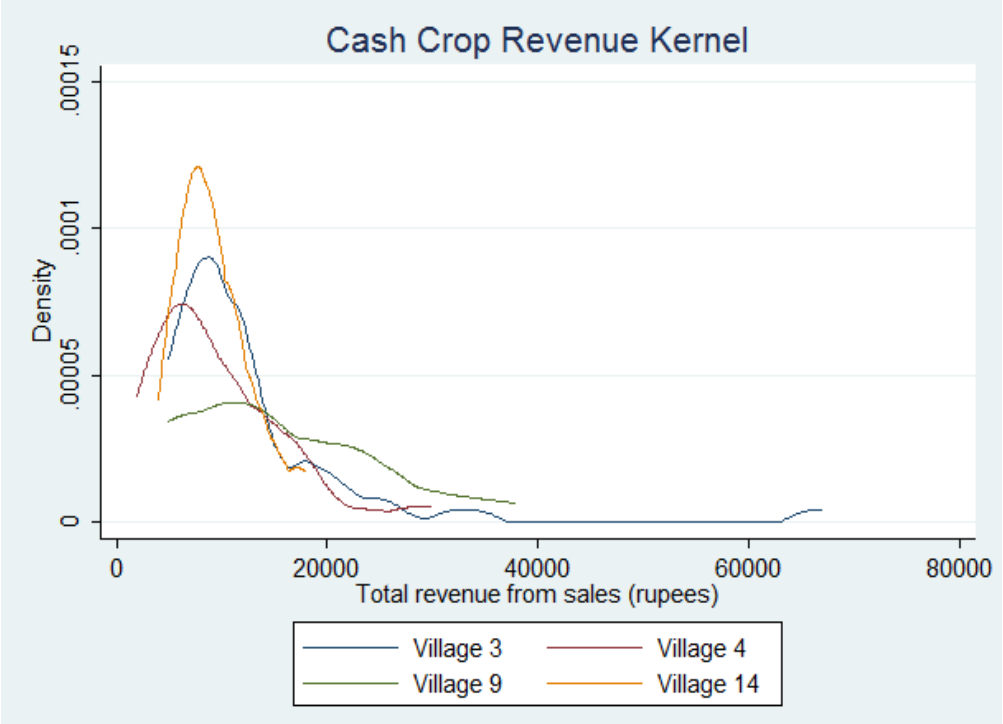

Figure 3: Cash Crop Revenue Kernel across Villages. 